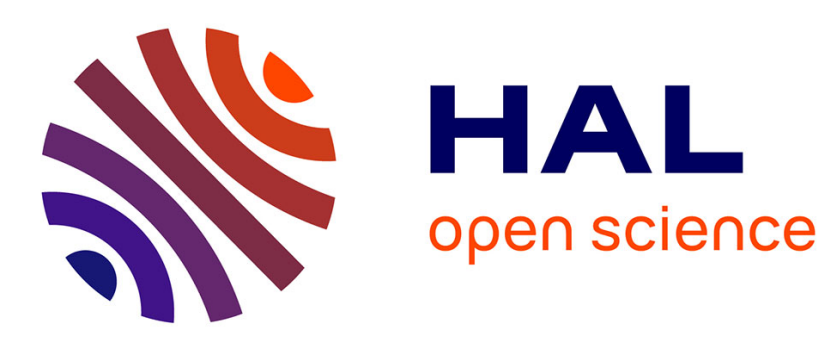

\title{
Fiscal Consolidations and Informality in Latin America and the Caribbean
}

\author{
Thibault Lemaire
}

\section{To cite this version:}

Thibault Lemaire. Fiscal Consolidations and Informality in Latin America and the Caribbean. 2020. halshs-02492309

\section{HAL Id: halshs-02492309 \\ https://shs.hal.science/halshs-02492309}

Submitted on 26 Feb 2020

HAL is a multi-disciplinary open access archive for the deposit and dissemination of scientific research documents, whether they are published or not. The documents may come from teaching and research institutions in France or abroad, or from public or private research centers.
L'archive ouverte pluridisciplinaire HAL, est destinée au dépôt et à la diffusion de documents scientifiques de niveau recherche, publiés ou non, émanant des établissements d'enseignement et de recherche français ou étrangers, des laboratoires publics ou privés. 


\section{Documents de Travail du

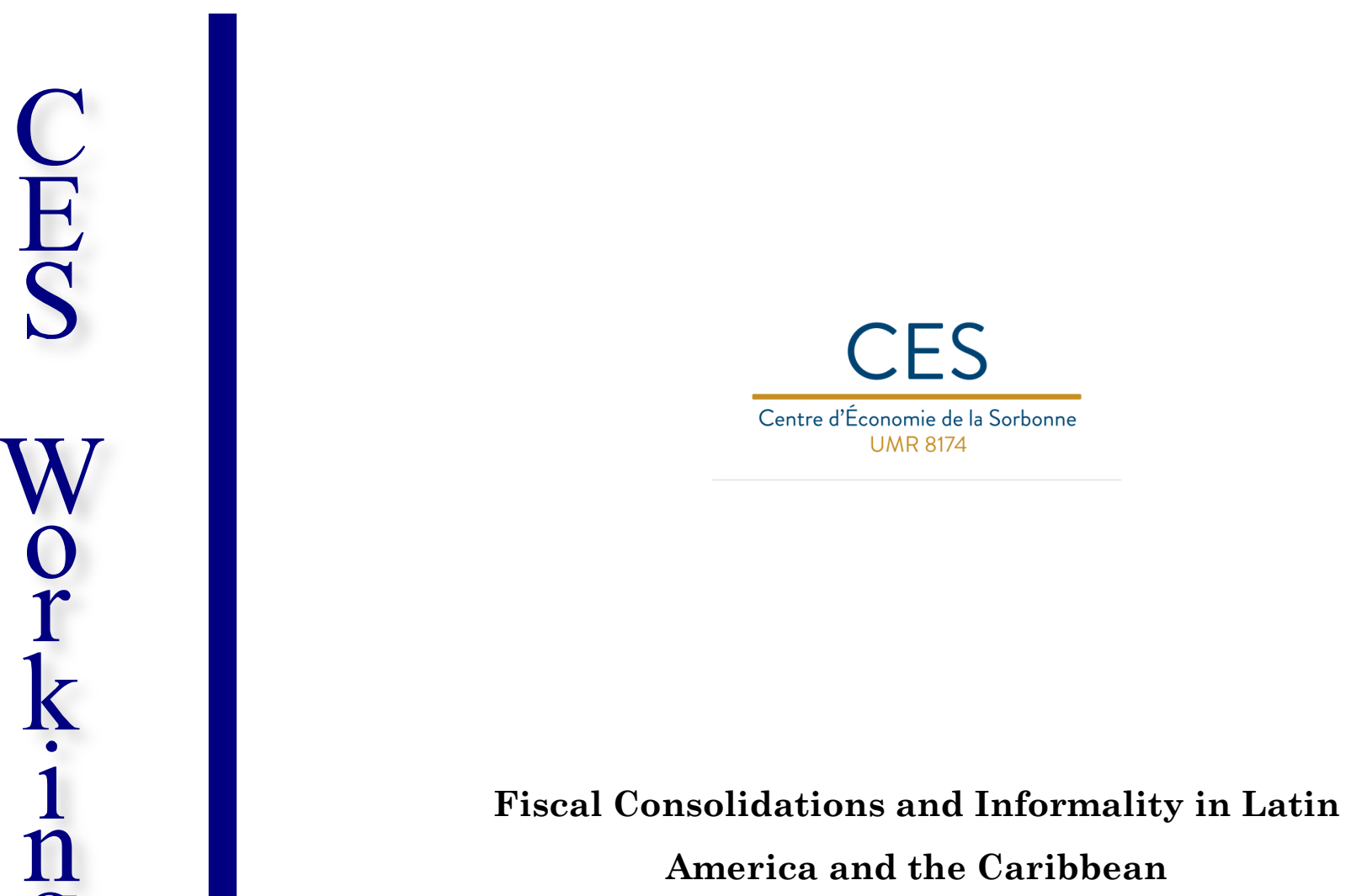

Thibault LEMAIRE

2020.04

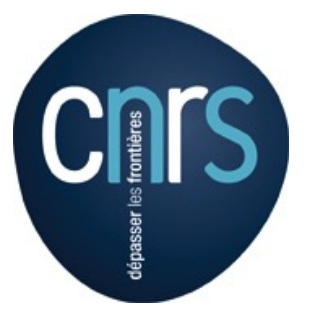




\title{
Fiscal Consolidations and Informality in Latin America and the Caribbean
}

\author{
Thibault Lemaire ${ }^{1,2}$
}

January, 2020

\begin{abstract}
The transmission mechanisms of fiscal policy are significantly affected by informality in the labour market. Extending a narrative database of fiscal consolidations in 14 countries from Latin America and the Caribbean between 1989 and 2016 in order to account for heterogeneity in terms of commitment to the reforms, I show that tax-based and spending-based multipliers are both recessionary and do not significantly differ one from another in this region. Furthermore, these multipliers decline in absolute value as the level of labour informality increases in the economy, although evidences are less robust for spending-based consolidations. An analysis of the effects of tax-based consolidations on private demand suggests that labour market informality constitutes a short-term social buffer that attenuates the contractionary effects of this type of policy by increasing investment opportunities through tax evasion and entrepreneurial alternatives to unemployment for dismissed workers.
\end{abstract}

Keywords: Fiscal consolidation, taxation, informality, emerging market economies.

JEL Classification: E62, E26, E32, H5, H6.

\footnotetext{
${ }^{1}$ Emails: thibault.lemaire@etu.univ-paris1.fr, thibault.lemaire@banque-france.fr. Affiliations: Centre d'Économie de la Sorbonne, Université Paris 1 Panthéon - Sorbonne; Banque de France.

${ }^{2} \mathrm{I}$ am deeply grateful to Jean-Bernard Chatelain for his advices, support and feedback. A special thank to Chahir Zaki and Jean Imbs for their invaluable comments at the beginning of this project. I also thank Rémi Bazillier, Josselin Thuilliez, Laurine Martinoty, Biagio Speciale, Mónica Gómez and seminar participants at Université Paris 1 Panthéon - Sorbonne for their very helpful comments. I am particularly grateful to Andrew Berg and José Antonio Ocampo for their highly inspiring comments and suggestions. The views expressed are mine and do not necessarily reflect those of Banque de France.
} 


\section{Introduction}

What should a Government do when the public finances are highly deteriorated, either due to a high public debt or to a large fiscal deficit? This question has always haunted policy makers, and recent research provides evidence that fiscal consolidations might indeed be electorally costly (Ardanaz et al., 2019; Chen et al., 2019; Kalbhenn and Stracca, 2020), perhaps because of their negative effects on well-being (Eklou and Fall, 2020). The contemporary history of Latin America and the Caribbean (LAC) provides many examples of fiscal mismanagement episodes that led to severe crises and negatively impacted the development prospects of the region, from the lost decade due to an unsustainable level of public debt to the extreme recession in Venezuela after oil prices, and government revenues, fell sharply. Budget mismanagement led to forty years of fiscal austerity in Jamaica, and a high and growing fiscal deficit generates concerns about the sustainability of Costa Rica's welfare system. On the contrary, improved fiscal management and sounder public finances in several countries of the region led to the implementation of countercyclical policies and therefore reduced the impact and duration of recent economic crises (Vegh and Vuletin, 2014; Miotti et al., 2012). In this context, it becomes highly important to understand which instruments are the most appropriate to prevent such dramatic events from happening and what the consequences of such interventions on the economy are.

In this article, I examine the effects of fiscal consolidations on output in LAC. Combining a database of fiscal consolidation episodes in this region with a database of informality in the labour market and with macroeconomic data, I ask whether the fiscal multiplier during consolidation episodes is affected by the level of labour informality in the economy. As this characteristic of developing countries is directly linked to a relatively smaller tax base than in countries with low levels of informality, the effect of a fiscal consolidation could affect a smaller share of the economic agents and therefore have a relatively smaller impact on total output. However, for the same reason, a fiscal consolidation accounting for a given percentage of GDP will likely have a greater impact on the formal sector of a highly informal economy than in an economy with low levels of informality, and therefore have a stronger impact on output. As the response of the fiscal multiplier to the presence of informality is undetermined, an empirical approach is suitable. I hypothesize that informality in the labour market affects significantly the transmission mechanisms of fiscal policy, and hence the fiscal multiplier.

Allingham and Sandmo (1972) have shown that tax-evasion, a determinant of informality, is determined by incentives. The literature on fiscal multiplier has a long and rich tradition but experienced a major change as Romer and Romer (2010) introduced the narrative approach as a new methodology to identify fiscal shocks that are not 
determined by the business cycle and that can therefore be considered as exogenous. Almost a decade after this methodology was adopted, Alesina et al. (2018) conclude that this new approach has led to robust results indicating that tax-based fiscal consolidations are more recessionary than spending-based fiscal consolidations in OECD countries. However, Carrière-Swallow et al. (2018) provide results that contradict this view as they find no difference between tax-based and spending-based multipliers in LAC. Acknowledging that informality might respond to incentives, and therefore to macroeconomic policy, and identifying the major role of this variable in determining the fiscal multiplier, recent theoretical insight from Pappa et al. (2015) and Dellas et al. (2017) based on models calibrated to match data from Mediterranean countries allow to reconcile the results obtained for OECD and emerging economies.

Based on these results, the contribution of this article is threefold. First, it extends an existing database (David and Leigh, 2018) by adding a measure of the announcement of the fiscal consolidation episode and computing an indicator of the commitment to the reform that captures the (ex-post) credibility of the policy maker. Second, it provides stronger evidence on the fiscal multiplier in LAC due to an improvement in the identification strategy. Third, it is, to my knowledge, the first study that shows empirically that the presence of informality in the labour markets affects the fiscal multiplier in emerging countries, and it presents stylized facts that highlight various transmission mechanisms that are affected by the structure of these labour markets.

To test the hypothesis that the fiscal multiplier is modified in the presence of informality, this article presents three exercises that rely on a database issued by the IMF (David and Leigh, 2018). Using the narrative approach, the authors include the exogenous fiscal consolidation episodes for 14 countries in LAC between 1989 and 2016. In order to assess the impact of the credibility of the reforms, I extend this dataset by including a measure of the fiscal policy announcement for each observation and by computing the difference between the realization and the announcement, expressed as a percentage of GDP. A negative value indicates that the result of the implementation was more modest than initially announced, and therefore that the reform was not fully credible. A zero value indicates that the reform was fully credible, and a positive value denotes an overachievement of the reform. The data on informality in these 14 countries come from the Socio-Economic Database for Latin America and the Caribbean (CEDLAS and The World Bank). The informality rate of the economy corresponds to two definitions, a productive and a legal definition, and is obtained from each country's household surveys. Data on commodity prices and demand come from Gruss and Kebhaj (2019). Other macroeconomic data come mainly from the World Development Indicators dataset (by The World Bank) and the International Financial Statistics 
dataset (by the International Monetary Fund).

In a first exercise, I estimate the multiplier of fiscal consolidations in LAC by a panel with time and country fixed effects and I control for the effect of the credibility of the policymaker on the multiplier. I find that the spending-based and tax-based multipliers are both recessionary but do not differ one from another in LAC. This second result is also found by Carrière-Swallow et al. (2018) but is contrary to the literature on advanced economies.

To understand this difference with respect to the literature on OECD countries, the second exercise consists in testing the hypothesis that informality alters the fiscal multiplier by estimating the multiplier for two separate groups of countries: the seven countries that have an informality rate above the median on the one hand, and the seven that are below this threshold on the other hand. Because of a low number of observations for spending-based reforms, only the results that concern the tax-based consolidations can be interpreted with a high level of confidence. I show that the fiscal multiplier is positively affected by the presence of informality during fiscal consolidations, which have therefore a less recessionary impact, all other things equal, in countries with large informal labour markets. To assess the robustness of this results, I present a series of tests that consist in excluding the credibility measure, considering an alternative definition of labour informality, and including an interaction term between fiscal consolidation and informality to compute the marginal effect of consolidations on output for different levels of informality. Because the endogeneity of informality to the business cycle is the main concern, I use an alternative measure of labour informality (i.e. the legal instead of the productive definition), I decompose the evolution of the informality rate in each country into a trend and a cyclical components using the Hodrick-Prescott filter and keep only the trend component that is more exogenous to the business cycle, and I finally take the lag value of informality. The results of the robustness checks confirm that labour informality affects the fiscal multiplier.

In a third exercise, I support the claim that the effect of informality on the fiscal multiplier is causal by first controlling for accompanying policies that have been identified as determinants of the size of the multiplier and by showing that the effect is robust to the inclusion of the real effective exchange rate, a time-varying measure of the level of taxation before the fiscal consolidation and a measure of trade openness. Then, I estimate the effect of fiscal consolidations on private demand, business and consumer confidence, and on informality to identify more precisely the transmission mechanisms that are affected by the level of informality. The results are broadly consistent with some recent models calibrated on southern European countries as they indicate that the effect of fiscal consolidation on investment is positively affected by informality and 
that informality responds positively to tax-based consolidations in countries that already had a large informal sector.

The remainder of the article is organized as follows. Section 2 reviews the literature and section 3 describes the data and presents some stylized facts on informality and fiscal policy in Latin America and the Caribbean. Section 4 details the empirical strategy. After a discussion on the empirical results and robustness checks in section 5, section 6 presents evidence on the transmission mechanisms. Finally, section 7 concludes.

\section{Related literature}

The notion of fiscal multiplier has been widely studied from both a theoretical and an empirical standpoint in the economic literature. Its origins can be traced back to Kahn (1931) and despite strong critics made by several schools of thought, it is still studied from the undergraduate level, within the IS-LM framework based on Keynes' General Theory (Keynes, 1936), and a great number of publications are still related to this topic. At the end of the nineties and after, various authors (such as Barry and Devereux, 1995; Alesina and Perotti, 1997; Hogan, 2004; Cogan et al., 2013) presented the hypothesis of expansionary fiscal contraction, based on a positive effect on expectations and confidence and a negative effect on wages (Agénor and Montiel, 2008). However, this approach has been criticized by several authors. Leigh et al. (2010) and Guajardo et al. (2014) find that fiscal consolidations have contractionary effects in advanced economies and argue, from an empirical standpoint, that standard methods used to assess the impact of fiscal consolidations lead to upward biased estimates. Breuer (2019) and Cohen-Setton et al. (2019) also warn against the use of methods such as the cyclically adjusted primary balance, although Yang et al. (2015) find that it leads to improved results when variables such as asset prices fluctuations and idiosyncratic country-level features of fiscal policy are taken into account. Furthermore, Chatelain and Ralf (2018), among others, highlight that output growth after a fiscal consolidation episode could be explained by accompanying policies such as an exchange rate devaluation, and this argument has been acknowledged by Alesina et al. (2018).

As the use of the cyclically-adjusted primary balance to account for fiscal shocks could not eliminate the persistence of identification issues, Blanchard and Perotti (2002) improved the existing empirical strategies by using institutional information and estimating a structural VAR model for the U.S. economy. Much work has followed and found that the contractionnary effect of fiscal consolidation is indeed important (Jordà and Taylor, 2016), especially in periods of low growth (Blanchard and Leigh, 2013; DeLong and Summers, 2012; Fatás and Summers, 2018). However, the empirical approach 
to study the fiscal multiplier has experienced a major shift with Romer and Romer (2010), who first introduced a narrative dataset of fiscal events, and this methodology has been widely adopted by the literature (as in Dabla-Norris and Lima, 2018; Amaglobeli et al., 2019). In this new approach, the exogeneity of the fiscal shock with respect to the business cycle is ensured by the selection of fiscal events based on their explicit motivation according to different official sources (government and international organizations reports, parliamentary documents or public discourses for example). Therefore, only fiscal policy changes aiming at improving public finances are included in the database, while measures adopted to alter the business cycle are excluded.

Using the narrative approach, Alesina et al. (2017) find that both tax hikes and spending cuts have a recessionary impact on output, and that this negative impact is significantly higher in the case of tax hikes. In a subsequent article, Alesina et al. (2018) argue that this more negative effect of tax-based fiscal consolidations with respect to spending-based fiscal consolidations is a strong, established result of the literature that uses the narrative approach. Nevertheless, the literature on the multiplier during fiscal consolidations has primarily focused on advanced economies and estimations of the Keynesian multiplier in developing countries have mainly been related to expansionary fiscal policies (such as Ilzetzki, 2011; Ilzetzki et al., 2013; Hory, 2016; Furceri and $\mathrm{Li}$, 2017). As in Honda et al. (2020), the conclusions of this literature tend to point towards a lower multiplier in developing countries than in advanced economies, although Izquierdo et al. (2019) find opposite results when considering only the public investment multiplier and Arizala et al. (2017), using the forecast errors and the Local Projection method developped by Jordà (2005), evidence that spending-based fiscal consolidations are more harmfull to the economy than tax-based consolidations in SubSaharan Africa.

In an IMF technical note, Batini et al. (2014) indicate that the theoretical and empirical results for low income and emerging countries are not clearly established, and relatively few studies have adopted the narrative approach to establish more robust empirical results. Because of their specificities, in terms of institutional context, level of development, exposure to financial and currency crisis, political instability, high inequalities, labour market structure, exchange rate regime, insertion in the world trade or export basket composition, size and development of the public sector (as evidenced for three LAC countries by Miotti et al., 2012), the conduct of macroeconomic policy in developing countries differs necessarily from practices in advanced economies, and the stabilization policies transmission mechanisms identified by the literature could be altered by these structural differences, whose importance has been highlighted by Boyer (2015). The political process leading to decision making is also very different from what 
is observed in advanced economies and this dimension cannot be neglected.

Using a narrative dataset of fiscal consolidation episodes in LAC elaborated by David and Leigh (2018), Carrière-Swallow et al. (2018) try to fill this gap in the literature and find that, contrary to the evidence obtained in advanced economies, the tax-based and spending-based fiscal multipliers are not significantly different one from another. The authors present further evidence indicating that the tax-based fiscal multiplier in LAC could be smaller in absolute value, i.e. less recessionary, than in OECD countries. Theoretical insights are still inconclusive to explain these striking results, but the presence of large informal labour markets is a likely explanation that I test in this article. In a seminal work, Allingham and Sandmo (1972) show that tax evasion is a rational decision that is driven by incentives. Because large informal labour markets provide agents with investment and employment opportunities that are absent from economies with low levels of informality, it is reasonable to assume that the effects of fiscal policy on output will be altered by the existence of such informal markets. For this reason, several recent articles have explored the economic policy transmission channels that are affected by the shadow economy, (such as Ait Lahcen, 2020; Alberola-Ila and Urrutia, 2019; Jaramillo et al., 2013).

In the case of OECD countries, Alesina et al. (2017) complement their empirical results with a theoretical reflexion in which they show that a simple Dynamic Stochastic General Equilibrium (DSGE) model specification can simulate the greater recessionary impact of a tax-based consolidation compared to a spending-based event. Pappa et al. (2015) present a different DSGE model that allows for tax evasion and corruption and that is calibrated to match Italian data. Their results indicate that labour informality reacts positively to tax hikes and negatively to spending cuts, and that the cost of such policies in terms of formal sector output evolves in the same direction (i.e. is increased in the case of tax-based consolidations and declines when it is spending-based). Dellas et al. (2017) choose to include to their model an informal productive sector to reassess the impact of the post-crisis consolidation package on the Greek economy and conclude that informality has increased the difficulty to stabilize public debt while generating an unnecessary but over-estimated decline in GDP. These results suggest that omitting the informal productive sector generates a recessionary bias for the tax-based multiplier estimates.

Costa et al. (2017) calibrate a DSGE model with an informal sector to match Brazilian data and assess the fiscal policy transmission mechanisms for different levels of informality. The authors find that the impact of tax-based consolidations on output is absorbed by the informal sector and is therefore somewhat positive. It is also higher when the informal sector is large, while the negative effect on consumption worsens 
with informality. Spending-based consolidations in this model have a moderate expansionary effect on output. The authors present theoretical results that cannot fully explain the findings of Carrière-Swallow et al. (2018). In order to fill this gap, this article contributes to the literature by providing empirical evidence on the effect of informality on the fiscal multiplier.

\section{Data and Stylized Facts}

The country-level data covers 14 Latin American and Caribbean economies ${ }^{1}$ that represented from $91.5 \%$ to $93.5 \%$ of the GDP of the region between 2010 and $2015 .^{2}$ The period spans from 1989 to $2016 .^{3}$ Table A.1 in appendix A reports the definitions and sources of the variables used in this empirical study.

The real GDP is from the World Development Indicators dataset while private consumption and investment come from the International Financial Statistics dataset and are expressed in base 100 (in year 2010). Consumer and business confidence indexes come mainly from central bank and academic sources, detailed in table A.2 in appendix A. In order to harmonize these indicators, they have first been linearly interpolated. Then, from the monthly series and growth rates, year observations have been computed as the average growth rate of the index during the year. The real effective exchange rate (REER) is from the Bruegel dataset (Darvas, 2012) and includes 67 trading partners. The commodity export value is from Gruss and Kebhaj (2019) and includes 45 commodities. Public revenues are from the IMF World Economic Outlook (April 2018).

Data for fiscal consolidations in LAC are from David and Leigh (2018). These authors use a narrative approach to identify fiscal consolidations that are explicitly motivated by long term objectives instead of being motivated by the desire to stabilize short-term fluctuations or by the anticipation of an economic downturn. The dataset include 76 consolidation episodes: 55 mostly tax-based, 18 mostly spending-based and 3 episodes that are balanced between these two components. Table 1 provides descriptive statistics for several variables: the fiscal consolidation dataset provides 66 tax-based and 30 spending-based measures. Spending-based consolidations are some-

\footnotetext{
${ }^{1}$ Argentina (ARG), Bolivia (BOL), Brazil (BRA), Chile (CHL), Colombia (COL), Costa Rica (CRI), Dominican Republic (DOM), Ecuador (ECU), Guatemala (GTM), Jamaica (JAM), Mexico (MEX), Paraguay (PRY), Peru (PER) and Uruguay (URY).

${ }^{2}$ Source: World Economic Outlook (April 2018). Venezuela is not included and accounts for 3\% to $5 \%$ of the regional GDP.

${ }^{3}$ As data is available in 2017 for Chile, a $0.23 \%$ of GDP tax-based and total consolidations are included in the dataset. See David and Leigh (2018) for the Chilean reform that started in 2014. All Fiscal consolidation and Credibility variables for the remaining countries take a missing value in 2017.
} 
what larger but have a lower standard deviation.

Data on informality comes from representative household surveys and is compiled in the Socio-Economic Database for Latin America and the Caribbean elaborated by the CEDLAS and The World Bank. Two measures are included, corresponding to two definitions: a productive and a legal definition. Panel A in table 1 provides descriptive statistics for these variables and Figure 1 shows the evolution of labour informality over the period in LAC, using the productive definition. In the remainder of the article, the productive definition is preferred to the legal one, for economic reasons and because it contains more observations, especially for Jamaica (4 instead of 1$)$. When ranking the countries according to their average informality rate, the group of the seven least informal countries include Chile, Uruguay, Costa Rica, Argentina, Mexico, the Dominican Republic and Brazil, with an average informality rate ranging from $36.02 \%$ to $53.12 \%$, according to the productive definition. The group of the seven most informal countries include Colombia, Ecuador, Guatemala, Peru, Paraguay, Jamaica and Bolivia, with an informality rate ranging from $60.48 \%$ to $70.85 \%$.

Table 1 - Descriptive Statistics

\begin{tabular}{lllll}
\hline \hline Variable & Obs. Mean Median Min. Max. $\begin{array}{l}\text { Standard Skew. Kurt. } \\
\text { Deviation }\end{array}$ \\
\hline
\end{tabular}

Panel A: Informality

$\begin{array}{lllllllll}\text { Informality rate } 1^{\mathrm{a}} & 226 & 53.13 & 52.95 & 30.74 & 76.52 & 11.81 & 0.08 & 1.73 \\ {\text { Informality rate } 2^{\mathrm{b}}}^{2} & 210 & 44.16 & 38.26 & 11.92 & 77.28 & 18.12 & 0.22 & 1.71\end{array}$

Panel B: Fiscal Consolidation ${ }^{c}$

\begin{tabular}{|c|c|c|c|c|c|c|c|c|}
\hline Total $^{\mathrm{d}}$ & 77 & 0.90 & 0.7 & -0.9 & 4.1 & 1.01 & 0.98 & 4.16 \\
\hline Tax-Based ${ }^{\mathrm{d}}$ & 66 & 0.71 & 0.5 & -0.9 & 4.1 & 0.86 & 1.12 & 5.82 \\
\hline Spending-Based ${ }^{\mathrm{d}}$ & 30 & 0.74 & 0.65 & -0.5 & 2.0 & 0.53 & 0.47 & 3.47 \\
\hline \multicolumn{9}{|c|}{ Panel C: Credibility } \\
\hline Total $^{\mathrm{d}}$ & 86 & -0.36 & 0 & -3.8 & 1.5 & 0.77 & -1.87 & \\
\hline Tax-Based ${ }^{\mathrm{d}}$ & 77 & -0.29 & 0 & -2.94 & 1.3 & 0.67 & -2.07 & \\
\hline Spending-Based ${ }^{\mathrm{d}}$ & 37 & -0.22 & 0 & -2.0 & 1.5 & 0.62 & -0.59 & \\
\hline
\end{tabular}

a Share of workers in informal jobs (productive definition). b Share of salaried workers in informal jobs (legal definition). $\quad{ }^{\mathrm{c}}$ Excludes zero observations. $\quad{ }^{\mathrm{d}}$ Mean, Median, Minimum and Maximum in \% of GDP. $\quad$ excludes zero observations only when no fiscal consolidation occured. 
Figure 1 - Labour informality rate in Latin America and the Caribbean

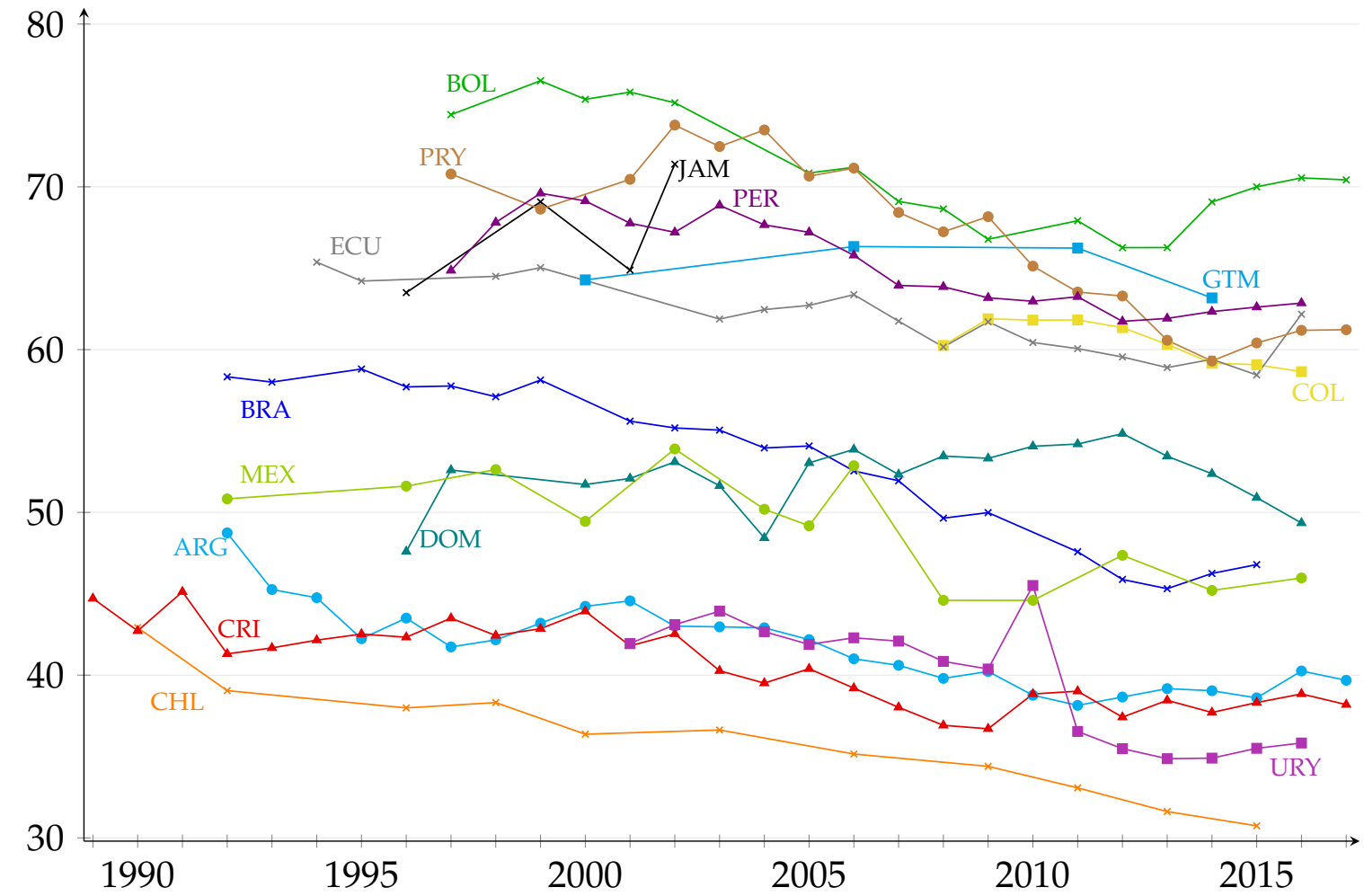

Source: CEDLAS and The World Bank, elaborated by the author. Labour informality corresponds to the productive definition and is expressed in percentage. This graph is better seen if printed in colour.

To elaborate a robust identification strategy, I construct a new dataset of fiscal consolidation credibility in LAC. David et al. (2019) provide evidence that the confidence effect, captured in the form of lower sovereign spreads, is an important transmission channel of fiscal shocks in developing countries. I use the fiscal consolidation dataset elaborated by David and Leigh (2018) and information provided by the authors that is complemented by IMF country reports and governmental documents. The credibility of the reform is an ex-post measure defined as the difference between the macroeconomic impact of the reform and the announced impact, both expressed in percentage of GDP. A positive value indicates that the impact of the implementation was greater than initially announced, while a negative value indicates that the impact of the implementation was smaller than initially announced. Zero indicates a full commitment to the reform: what was announced was implemented. Full details on the construction of the dataset are provided in Appendix B and the dataset is reported in table B.1. Fully credible reforms represent $65 \%$ (43 out of 66 ) of all implemented tax-based fiscal consolidations, while this percentage falls to 53\% (16 out of 30) in the case of implemented spending-based fiscal consolidations. Table 1 reports descriptive statis- 
tics excluding zeros observations when no fiscal consolidation occurred and including therefore fiscal consolidations that were announced but were not implemented. On average, spending-based consolidations have been slightly more credible than tax-based ones, as the mean of credibility for spending-based consolidations is -0.22 , versus -0.29 for tax-based consolidations. 27 announced tax-based consolidations were not fully implemented, while 7 reforms had a greater impact than what had been announced. In the case of spending-based consolidations, 17 announced reforms were not fully implemented, while 4 had an impact greater than what had been announced.

\section{Empirical Strategy}

I follow Jordà (2005) and Auerbach and Gorodnichenko (2012) and adopt a singleequation strategy, the Local Projection method, to study the effect of fiscal consolidation on output growth by estimating equation (1) for horizons $h=0,1,2$ and consolidation type $f=$ Total, Tax-Based, Spending-Based:

$$
g_{i, t+h}-g_{i, t-1}=\beta_{h, f} \sum_{p=t}^{t+h} F C_{i, p, f}+\delta_{h, f} \sum_{p=t}^{t+h} \operatorname{Cred}_{i, p, f}+\lambda \mathbf{X}_{i, t, f}^{\prime}+\alpha_{i}^{h}+\gamma_{t}^{h}+\varepsilon_{i, t+h}
$$

where $i$ denotes the country and $t$ the year. $g_{i, t}$ is the log of real GDP, $F C_{i, p, f}$ indicates the measure of fiscal consolidation expressed in percent of GDP and Cred ${ }_{i, p, f}$ denotes the measure of the credibility of reforms, also expressed in percent of GDP. The vector $\mathbf{X}_{i, t, f}^{\prime}$ denotes a set of additional control variables including two lags of total fiscal consolidation, two lags of real GDP growth, the contemporaneous growth rate of the commodity export value and its two lags, as well as two lags of the total credibility index and two lags of the respective credibility index for tax-based and spending-based consolidations. $\alpha_{i}^{h}$ denotes country fixed effects and captures countryspecific time-invariant factors, such as institutions or geography, that may affect output growth, while $\gamma_{t}^{h}$ denotes time fixed-effects and captures common shocks. Estimates are reported with the Driscoll and Kraay standard errors, that are robust to both crosssectional dependence and autocorrelation, additionally to heteroskedasticity (Driscoll and Kraay, 1998).

$\beta_{h, f}$ is the main coefficient of interest and corresponds to the estimated fiscal multiplier, defined as the response of the level of output to the cumulative fiscal consolidation of type $f$ at horizon $h$. Alesina et al. (2017) build on a vast literature and elaborate for the first time an identification strategy for 17 OECD countries that explicitly takes into account the fact that fiscal consolidations consist more in multi-year plans than in 
single-year reforms. However, their strategy relies on the crucial assumption that plans are fully credible, i.e. that measures that were announced were fully implemented. In addition to limited data availability for LAC, what can be considered a strong assumption (as the authors acknowledge) in the case of advanced economies would lead to an unreliable identification strategy in the case of developing countries. Therefore, I develop instead an identification strategy that explicitly accounts for the possible lack of commitment of policy makers after an announcement of fiscal consolidation.

Based on the narrative dataset elaborated by David and Leigh (2018), I compute for each observation of fiscal consolidation a measure of the announced effect of the reform, in percent of GDP, and a measure of the credibility of the reform, as explained in section 3. Announced reforms that were identified as exogenous to the business cycle but that were not implemented or were offset by other measures are also assigned a negative value in the credibility index. As the credibility of a reform is likely to partly determine the reaction of economic agents, controlling for this variable is important to identify more precisely the macroeconomic impact of an exogenous fiscal shock and represents one of the contributions of this article to the literature. However, endogeneity issues could affect this strategy, as the credibility index would be a bad control (Angrist and Pischke, 2008) if it could be predicted by either the size of the fiscal consolidation or the business cycle. Figure A.1 and figure A.2 in appendix A show that the credibility index is not correlated to the size of the fiscal consolidation nor to the business cycle. Correlation coefficients are low and not significant, and are reported in table A.3.

Carrière-Swallow et al. (2018) provide evidence that, contrary to what is usually found for advanced economies (Alesina et al., 2018), tax-based and spending-based fiscal multipliers do not differ one from another in LAC. To test the hypothesis that this absence of difference between the two multipliers in LAC is due to the presence of a high level of informality in the labour market, I rank the countries according to their average rate of informal labour and divide them into two groups : the group of highly informal countries, where the informality rate is higher than $60 \%$, and the group of relatively lowly informal countries, where the informality rate is lower than $54 \%$. Then, equation (2) is estimated for each group, for horizons $h=0,1,2$ and consolidation type $f=$ Total, Tax-Based, Spending-Based:

$$
y_{i, t+h}-y_{i, t-1}=\beta_{h, f} \sum_{p=t}^{t+h} F C_{i, p, f}+\delta_{h, f} \sum_{p=t}^{t+h} \operatorname{Cred}_{i, p, f}+\lambda \mathbf{X}_{i, t, f}^{\prime}+\alpha_{i}^{h}+\gamma_{t}^{h}+\varepsilon_{i, t+h}
$$

where $y_{i, t}$ is the variable of interest: the log of real GDP, private consumption and in- 
vestment as a share of GDP, and the average growth rate of the business and consumer confidence index, among others. All other variables are the same as in equation (1).

\section{Results and Robustness Checks}

Figure 2 reports the cumulative impulse response of output to a 1\% of GDP total fiscal consolidation (left-hand side) and to a 1\% of GDP tax-based and spending-based fiscal consolidation (right-hand side). The estimated (total) fiscal multiplier after two years has a value of -0.84 and is very similar to the findings of Carrière-Swallow et al. (2018). Additionally, these result bring further evidence that tax-based and spending-based fiscal multipliers do not significantly differ from each other in LAC, contrary to what is usually observed in advanced economies (Alesina et al., 2018). Using an identification strategy that includes a measure of the credibility of the consolidations seem to have closed the gap between the tax-based and spending-based multipliers, while maintaining relatively unchanged the overall fiscal multiplier. Tax-based consolidations appear to have a recessionary impact, while the impact of spending-based consolidations is not significantly different from zero. However, this latter result must be nuanced, as the confidence interval is very large for spending-based consolidations due to a small number (30) of non-zero observations.

Figure 2 - Impact of Fiscal consolidation on GDP

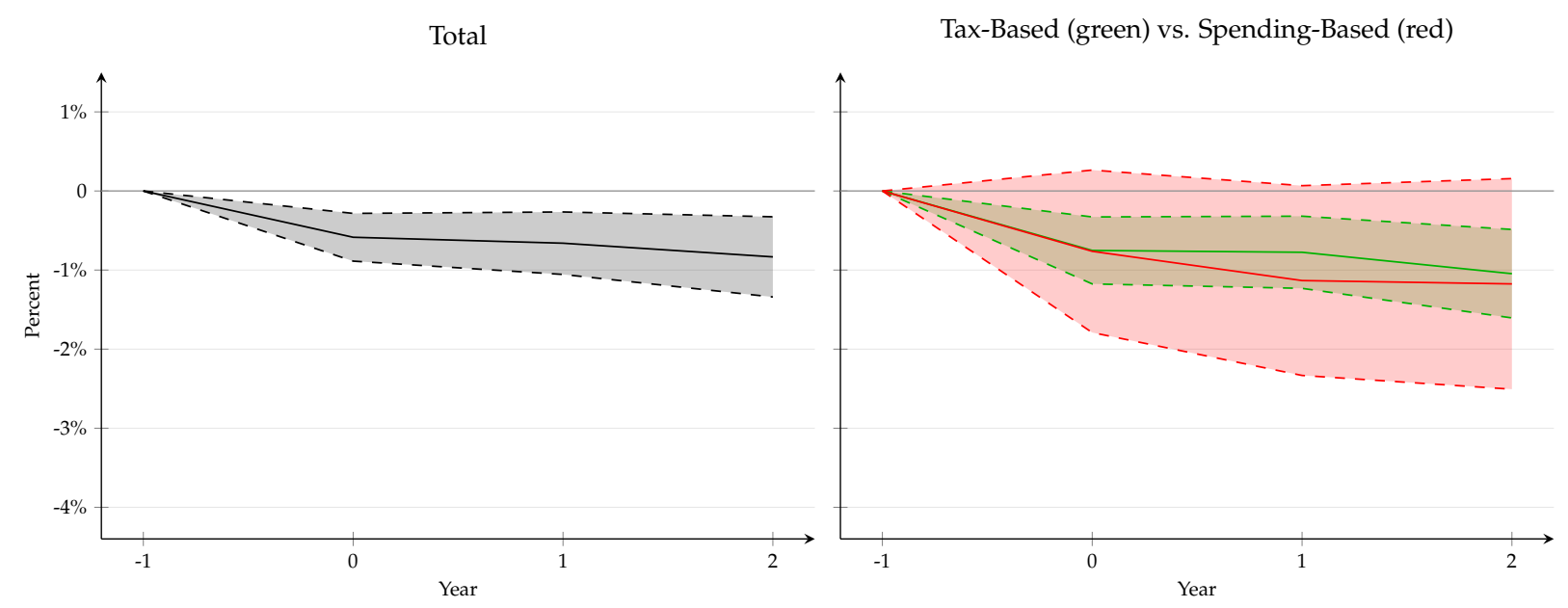

Note: The plain lines denote the cumulative response of real GDP to a fiscal shock, the shaded areas denote the $90 \%$ confidence interval.

Figure 3 reports and compares the cumulative impulse response of output to a $1 \%$ of GDP total fiscal consolidation (left-hand side) and to a 1\% of GDP tax-based and spending-based fiscal consolidation (right-hand side) for lowly (below the median) 
and highly (above the median) informal countries. For each type of fiscal consolidation, the fiscal multiplier is significantly higher (i.e. the effect of a consolidation is less recessionary) in countries with a high average level of labour informality than in countries with low levels of informality. In line with what is observed by Carrière-Swallow et al. (2018) for the whole sample, some weaker evidence suggest that the tax-based and spending-based multipliers might differ one from another in countries with reduced informal labour markets: contrary to the most common findings in OECD countries but in line with results for low income countries (Arizala et al., 2017), spending-based consolidations seem to have a more recessionary impact than tax-based consolidations in LAC. However, for the reasons explained above, the results regarding the spendingbased multiplier are not fully conclusive. ${ }^{4}$

Figure 3 - Impact of Fiscal consolidation on GDP: Low vs. High Informality

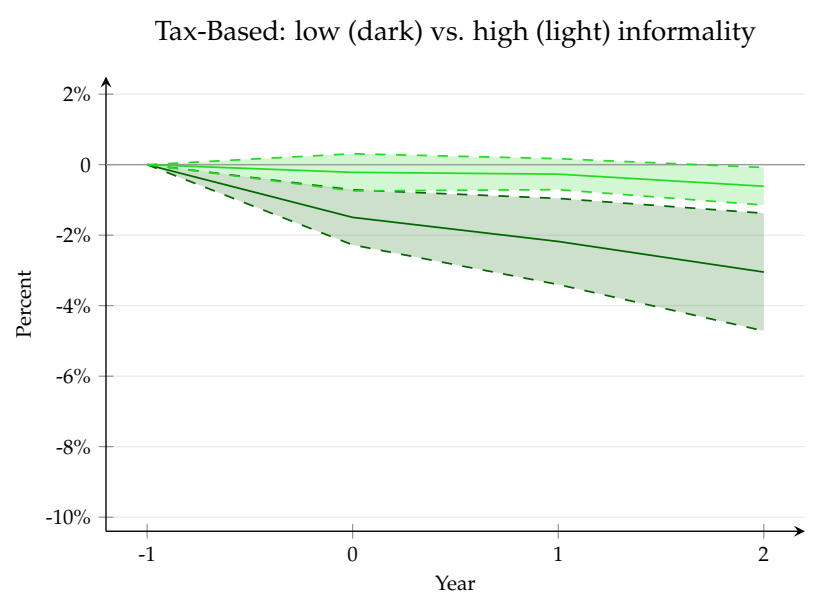
Spending-Based: low (dark) vs. high (light) informality

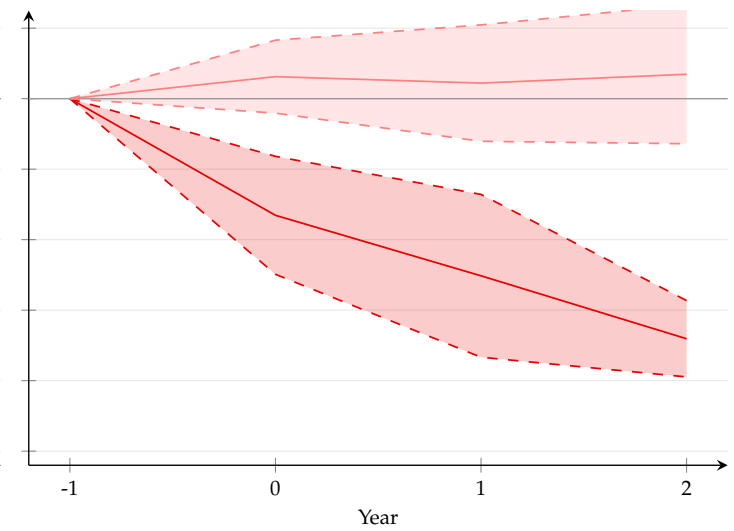

Total: low (dark) vs. high (light) informality

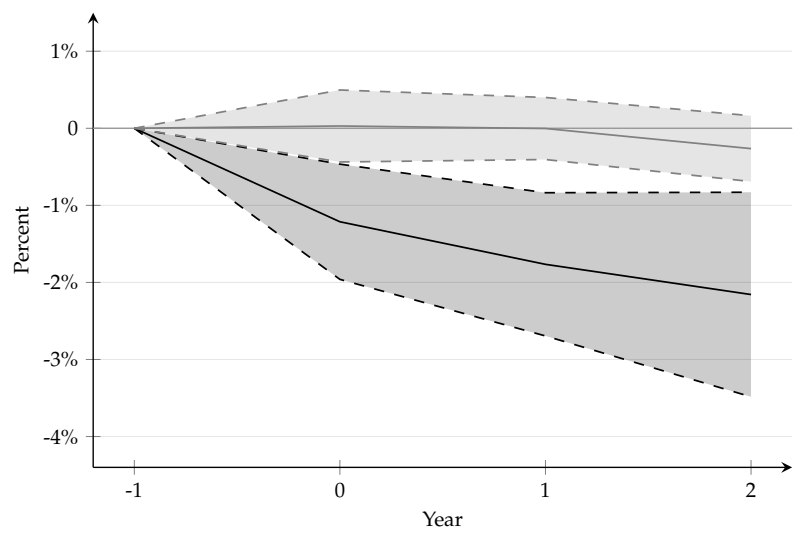

Note: The plain lines denote the cumulative response of real GDP to a fiscal shock, the shaded areas denote the $90 \%$ confidence interval. 


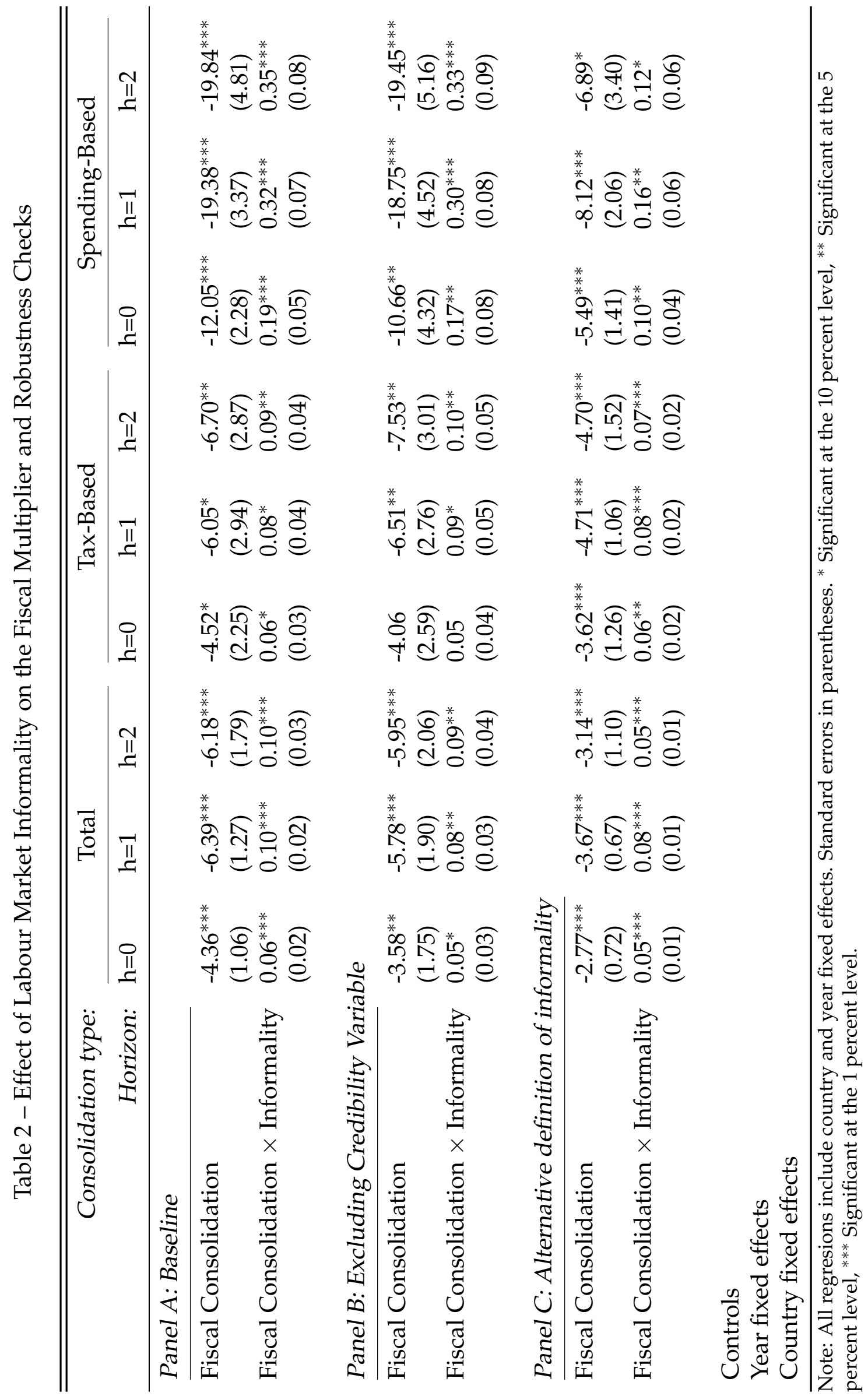


Panel A in table 2 reports comparable results, obtained from the estimation of equation (3):

$$
\begin{aligned}
y_{i, t+h}-y_{i, t-1}=\beta_{h, f} \sum_{p=t}^{t+h} F C_{i, p, f}+\eta I_{i, t} & +\varphi_{h, f} \sum_{s=t}^{t+h} F C_{i, s} * I_{i, t}+\delta_{h, f} \sum_{p=t}^{t+h} \operatorname{Cred}_{i, p, f} \\
& +\lambda \mathbf{X}_{i, t, f}^{\prime}+\alpha_{i}^{h}+\gamma_{t}^{h}+\varepsilon_{i, t+h}
\end{aligned}
$$

where $I_{i, t}$ is the informality rate in country $i$ during year $t$. All remaining variables remain as in equations (1) and (2). $\beta$ corresponds in this case to the estimated fiscal multiplier for an economy with zero informality on the labour market, while $\varphi$ indicates the effect of a one percentage point increase in the informality rate on the fiscal multiplier.

Figure 4 - Marginal Effects of Fiscal Consolidation on Output
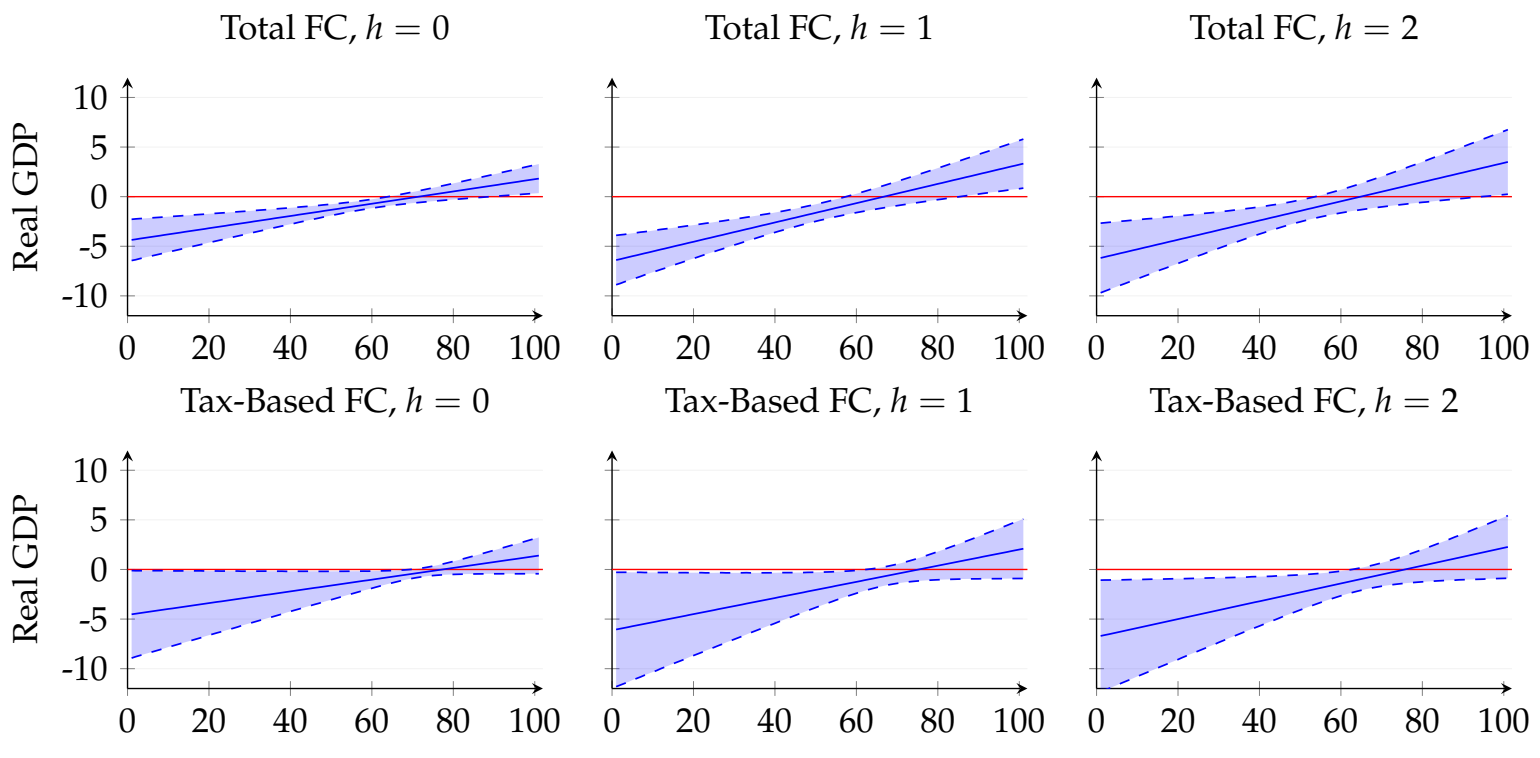

Spending-Based FC, $h=0$

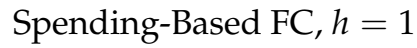

Spending-Based FC, $h=2$
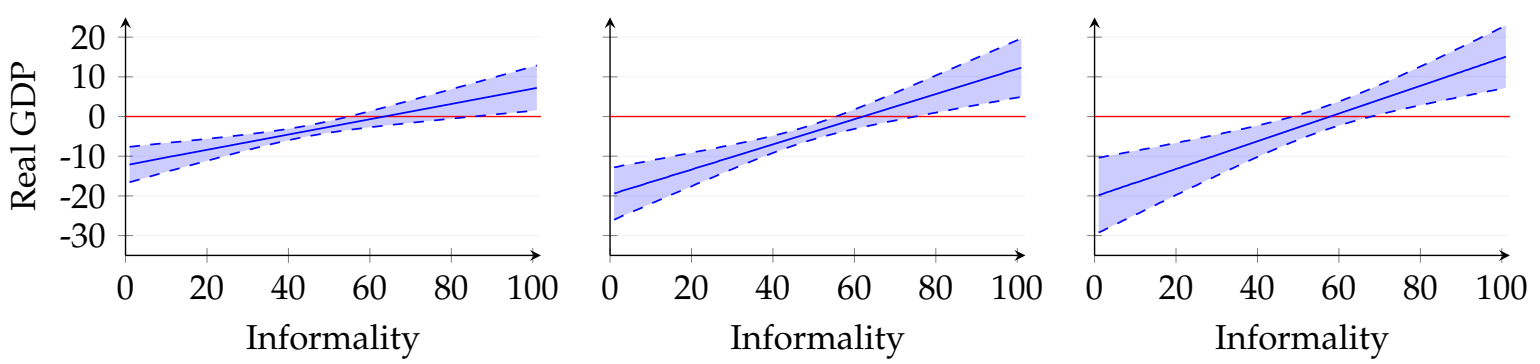

Note: The graphs show the effect of total, tax-based and spending-based fiscal consolidations on output at horizons $h=0,1,2$ for different levels of labour informality. The shaded areas correspond to the $95 \%$ confidence interval. The informality rate corresponds to the share of workers in informal jobs (productive definition).

\footnotetext{
${ }^{4}$ Results are available from the author upon request.
} 
Estimates presented in table 2 indicate that in a (fictious) economy with no informal labour market, a total fiscal consolidation amounting to $1 \%$ of GDP would lead to a $4.37 \%$ decline in output during the year of implementation, while a consolidation of the same magnitude will only lead to a $1.37 \%$ decline in output in an economy where informality accounts for $50 \%$ of the labour market.

To examine the robustness of the positive impact of labour market informality on the fiscal multiplier, I undertake a series of exercises. Panel B in table 2 reports the estimates obtained from equation (3) when the credibility variable and its lags are not included. The value of the estimates is only slightly higher (i.e. the effect of consolidations is less recessionary) and the statistical significance is unaffected. Therefore, the results are not driven by the inclusion of the credibility variable. Estimates obtained using the legal definition of labour informality instead of the productive definition are presented in table 2, panel $\mathrm{C}$. The coefficients are lower than when using the productive definition and remain highly significant. The marginal effects of total, tax-based and spending-based fiscal consolidation on output according to the labour market informality rate are represented at horizon $h=0,1,2$ in figure 4 and confirm that the fiscal multiplier is altered by labour informality. This result is also robust to the use of an alternative informality variable, corresponding to the legal definition. ${ }^{5}$

A major challenge to the causal interpretation of the effect of labour informality on the fiscal multiplier is the possibility of reverse causality. To ensure that the results are robust to this possibility, I undertake two additional robustness checks. Labour market informality is likely to be determined by both structural factors, such as the composition of the productive sector and the characteristics of regulations, and cyclical fluctuations. In this case, fiscal consolidations that are exogenous to the business cycle should only impact the cyclical component of labour market informality while the trend should remain unaltered, at least in the short-term. Therefore, after linearly interpolating the informality rate time series, ${ }^{6}$ the first robustness check, which aims at ensuring that endogeneity is not driving the results, consists in first decomposing the time series to obtain a trend and a cyclical components using the Hodrick-Prescott filter (with a smoothing parameter of 100), and then including only the more exogenous trend component in the interaction term in equation (3). The marginal effects of the different types of consolidation on output using the trend component of the productive definition of labour informality are represented in figure 5 and evidence that the

\footnotetext{
${ }^{5}$ The results are available from the author upon request.

${ }^{6}$ The marginal effects using these interpolated series are available from the author upon request and show the same pattern as the original series.
} 
results are robust to this exercise. ${ }^{7}$

Figure 5 - Marginal Effects of Fiscal Consolidation on Output Using the Trend Component of Informality
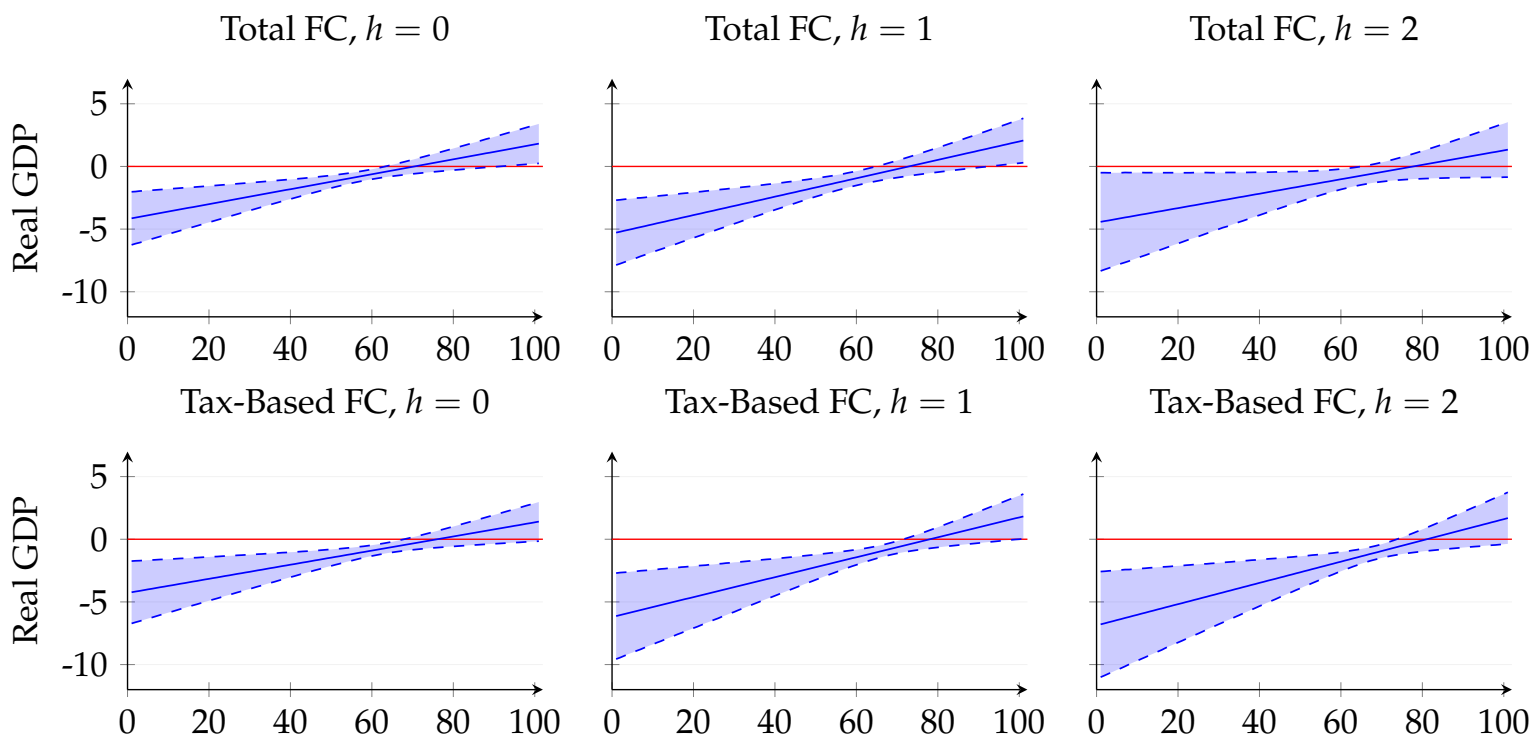

Spending-Based FC, $h=0$

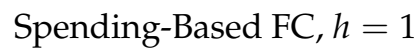

Spending-Based FC, $h=2$
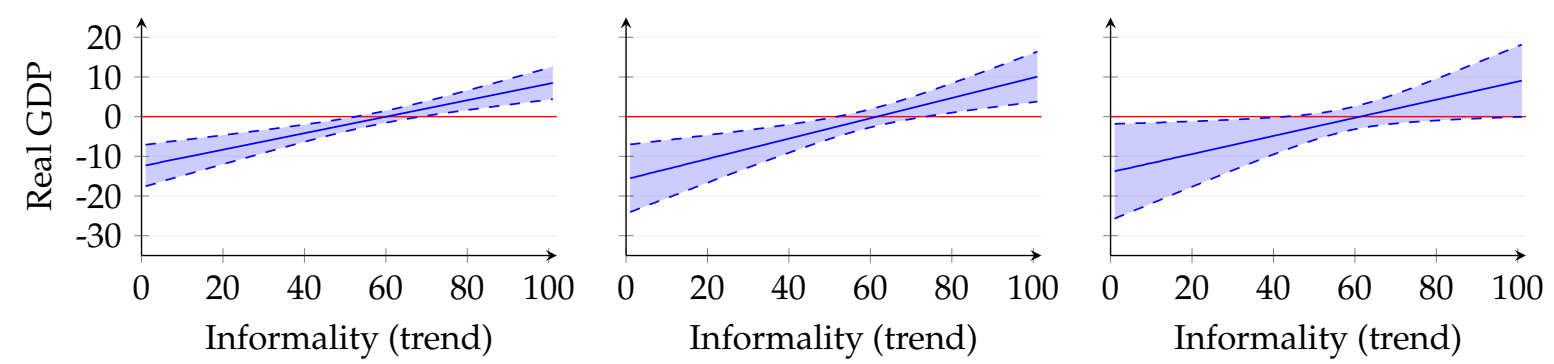

Note: The graphs show the effect of total, tax-based and spending-based fiscal consolidations on output at horizons $h=0,1,2$ for different levels of labour informality. The shaded areas correspond to the $95 \%$ confidence interval. The variable for informality corresponds to the trend component of the linearly interpolated series of the share of workers in informal jobs (productive definition). The trend component is obtained from the Hodrick-Prescott filter, with a smoothing parameter of 100.

Despite the fact that a higher degree of exogeneity is ensured when keeping only the trend component of informality, I perform a second robustness check aiming at ensuring that the results are not driven by endogeneity by using the lag value of the informality rate, which is not affected by and uncorrelated to an exogenous fiscal shock. As evidenced in figure 6 , the results are also robust to this test. ${ }^{8}$ An additional robustness

\footnotetext{
${ }^{7}$ Results are also significant when using the legal definition of labour informality and are available from the author upon request.

${ }^{8}$ Figure 6 shows the results for the productive definition of labour informality. The results for the legal definition are available from the author upon request and lead to the same conclusion.
} 
check, also leading to the conclusion that the results are robust, consists in using an alternative division of the sample of countries, based on their initial level of informality during the period instead of their average informality rate. ${ }^{9}$

Figure 6 - Marginal Effects of Fiscal Consolidation on Output Using the Lag of the Informality Rate

Total FC, $h=0$
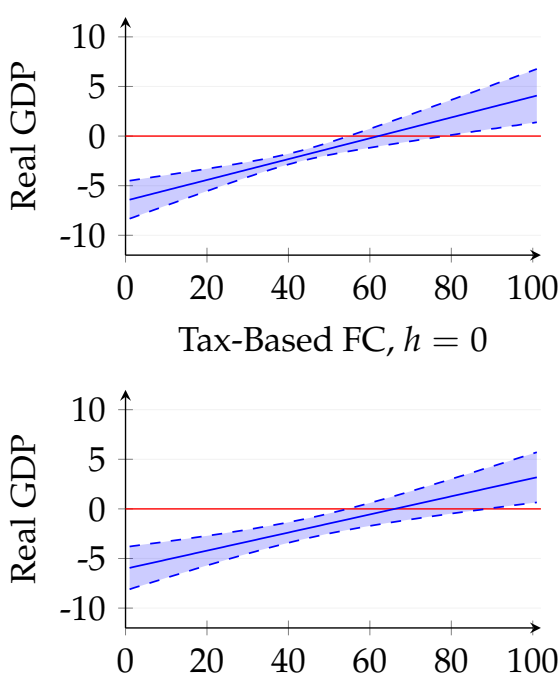

Spending-Based FC, $h=0$

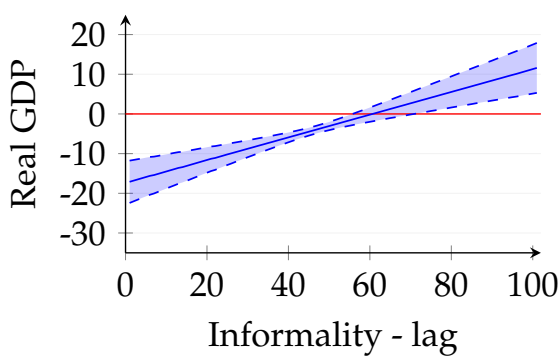

Total FC, $h=1$
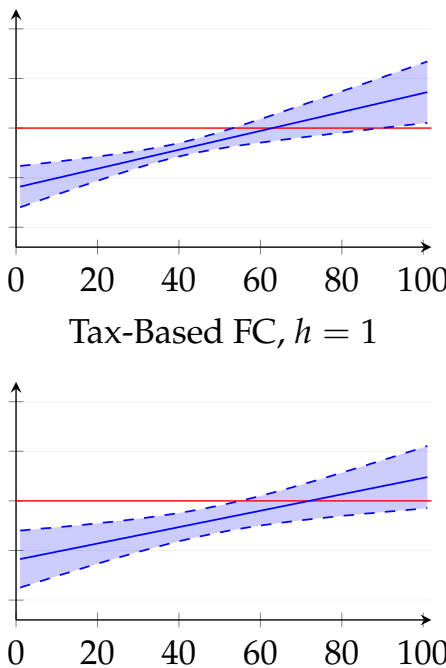

Spending-Based FC, $h=1$

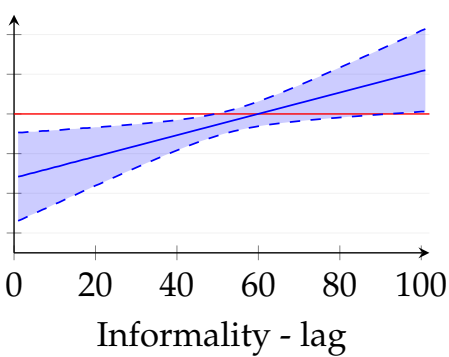

Total FC, $h=2$
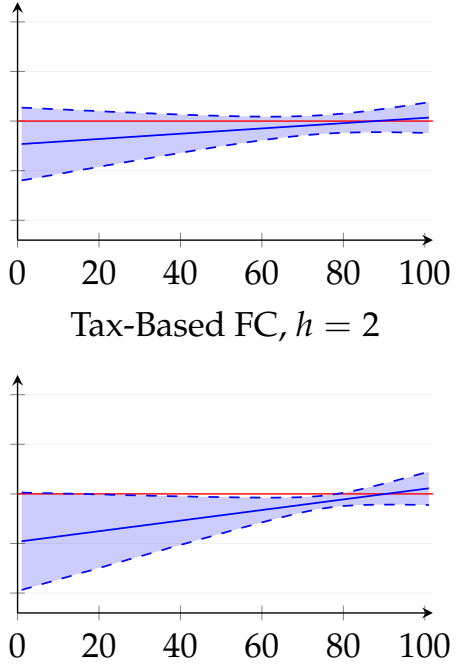

Spending-Based FC, $h=2$

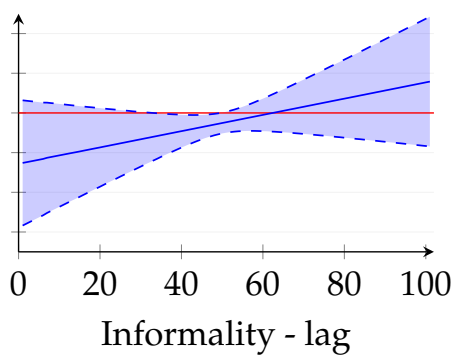

Note: The graphs show the effect of total, tax-based and spending-based fiscal consolidations on output at horizons $h=0,1,2$ for different levels of labour informality. The shaded areas correspond to the 95\% confidence interval. The variable for informality corresponds to the one-year lag (i.e. at $t-1$ ) of the share of workers in informal jobs (productive definition).

The difference in the fiscal multipliers between countries that are below and above the median informality rate could be explained by accompanying policies. For example, a concomitant real devaluation will likely have a positive impact on output, depending on the elasticity of the tradable sector of the economy, which may be attributed to the consolidation if the real exchange rate is not included in the regression.

\footnotetext{
${ }^{9}$ Results are available from the author upon request.
} 
The same is true for trade openness, and the overall level of taxation in the economy may also impact the different responses of the agents to a fiscal consolidation. If these variables are correlated with the informality rate in the labour market, the estimated multiplier could be biased.

Figure 7 - Impact of Fiscal consolidation on GDP: low vs. high informality, controlling for exchange rate, level of taxation and trade openness

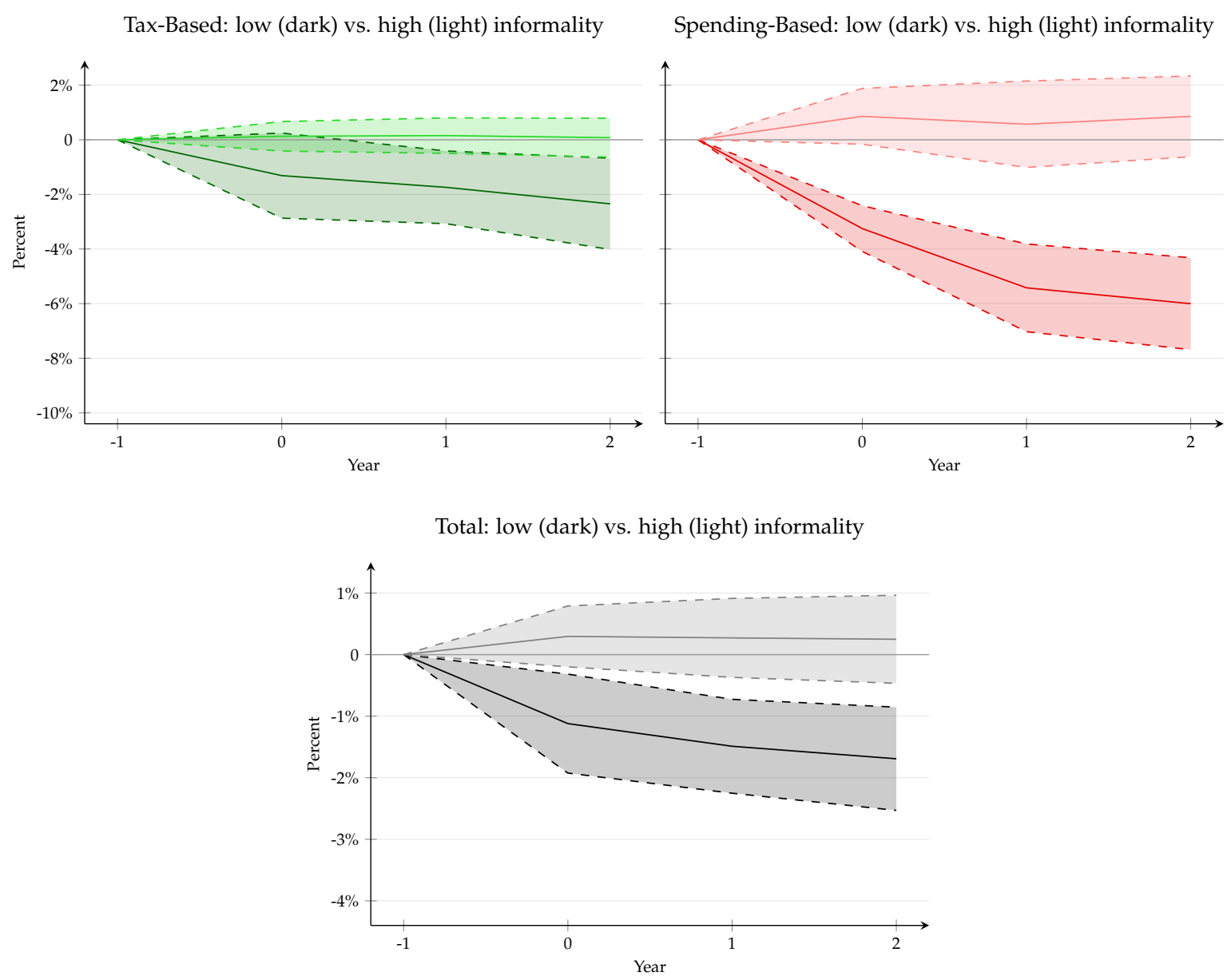

Note: The plain lines denote the cumulative response of real GDP to a fiscal shock, the shaded areas denote the $90 \%$ confidence interval.

Therefore, I include the contemporary REER growth rate and its two lags, as well as a measure of the taxation level and trade openness, as additional control variables in equation (2) and estimate it separately for lowly and highly informal countries. As the taxation level is mechanically endogenous to fiscal consolidations, a first best would be to consider only the first observation for each country. However, this variable would disappear in a regression with country fixed effects. Therefore, in order to obtain an exogenous and time-variant measure of the taxation level in each country, I take the 
average taxation level of up to the ten previous years. This allows to have only lag values of taxation while losing only the initial observation for each country.

Figure 7 reports the response of output to tax-based, spending-based and total fiscal consolidation when the REER, the trade openness variable and the taxation level are included in the set of controls: even with the inclusion of these three additional controls for accompanying policies, the fiscal multiplier is positively affected by the presence of informality in the labour market, as the effect of a consolidation is significantly more recessionary in the countries with a below-the-median informality rate than in the countries in which the informality rate is above this threshold. ${ }^{10}$

\section{Transmission Mechanisms}

In this section, I present estimates of equation (2) that use alternative dependent variables in order to analyse the impact of fiscal consolidation on private demand components (consumption and investment), on consumer and business confidence, and on labour informality. All estimations add two lags of the dependent variable to the previous vectors of controls. Due to the small number of observations for spending-based consolidations, the analysis in this section will focus mainly on the effects of tax-based consolidations.

Figure 8 reports the response of private consumption to the three different types of fiscal shocks according to the relative level of labour informality in the economy. Total, tax-based and spending-based consolidation have a recessionary impact in countries with low informal sectors, immediately in the case of spending-based consolidations and after one year in the case of tax-based consolidations. In highly informal economies, the effect of a tax-based consolidation does not seem different, as it also becomes recessionary after one year, while the effect of a spending-based consolidation in a context of high informality does not seem to have any recessionary impact.

Results of the estimated effect of consolidations on consumer confidence, reported in figure 9 for economies with reduced informal sectors, are useful to explain this result. ${ }^{11}$ Both total and tax-based consolidations have a significantly positive effect on the consumer confidence index growth rate during the year of implementation, which might explain the delayed recessionary effect of these types of consolidation on consumption. On the contrary, spending-based consolidations do not lead to significant

\footnotetext{
${ }^{10}$ Including each of these additional controls alternatively leads to similar results, that can be obtained from the author upon request.

${ }^{11}$ As reported in table A.2, data for consumer confidence index is only available in two highly informal countries (Colombia and Ecuador) and therefore results are only available for the seven least informal countries.
} 
variations in this index, which therefore does not prevent consumption from declining from the year of implementation.

Figure 8 - Impact of Fiscal Consolidation on Consumption: Low vs. High Informality

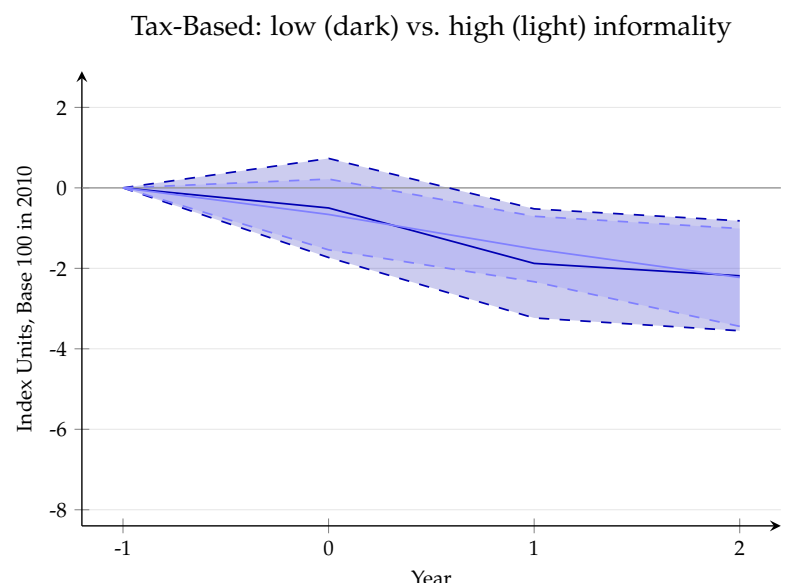
Spending-Based: low (dark) vs. high (light) informality

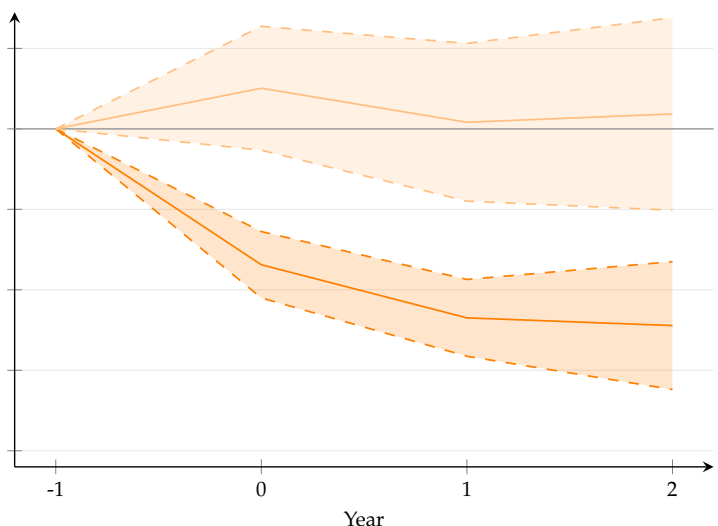

Total: low (dark) vs. high (light) informality

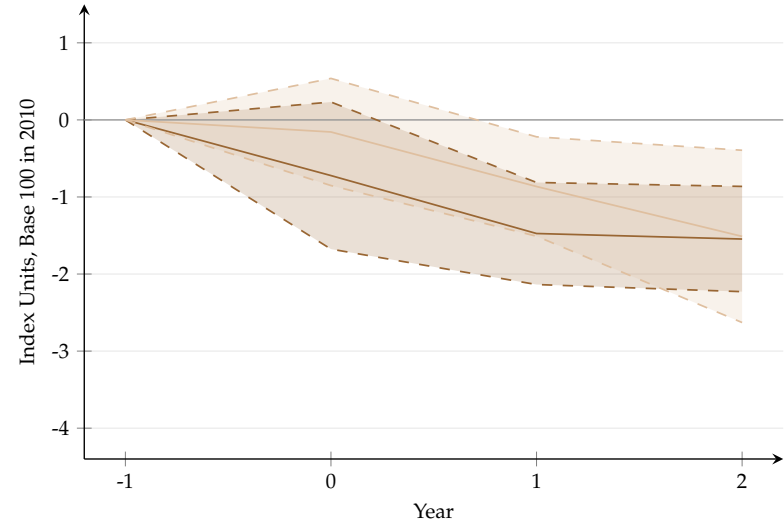

Note: The plain lines denote the cumulative response of private consumption to a fiscal shock, the shaded areas denote the $90 \%$ confidence interval.

These results, a negative but delayed effect of tax-based consolidation on consumption and a positive effect on consumer confidence, are different from the findings of Alesina et al. (2017) for OECD countries. Acknowledging that anticipations may determine the response of economic agents to consolidations, these results suggest that anticipations could be affected in two opposite directions by a tax-based consolidation in LAC: on the one hand, agents might foresee a negative impact on their personal disposable income leading to a decline in consumption, while on the other hand, given the very low levels of public revenues in the region, ${ }^{12}$ they might anticipate a positive

\footnotetext{
${ }^{12}$ According to OECD et al. (2019), public revenues account for less than $14 \%$ of GDP in Guatemala, Paraguay and the Dominican Republic.
} 
aggregate impact through sounder public finances and increased provision of public goods and services. The results suggest that while the latter effect may offset the former at the time of the reform implementation, the former may predominate in subsequent periods. In LAC, the absence of positive anticipations following spending-based consolidations may be explained by the fact that these episodes can negatively and severely affect the provision of scarce public goods and services and the investment in infrastructure. However, limited data availability does not allow to test this argument.

Figure 9 - Impact of Fiscal Consolidation on Consumer Confidence in Countries With Low Levels of Informality

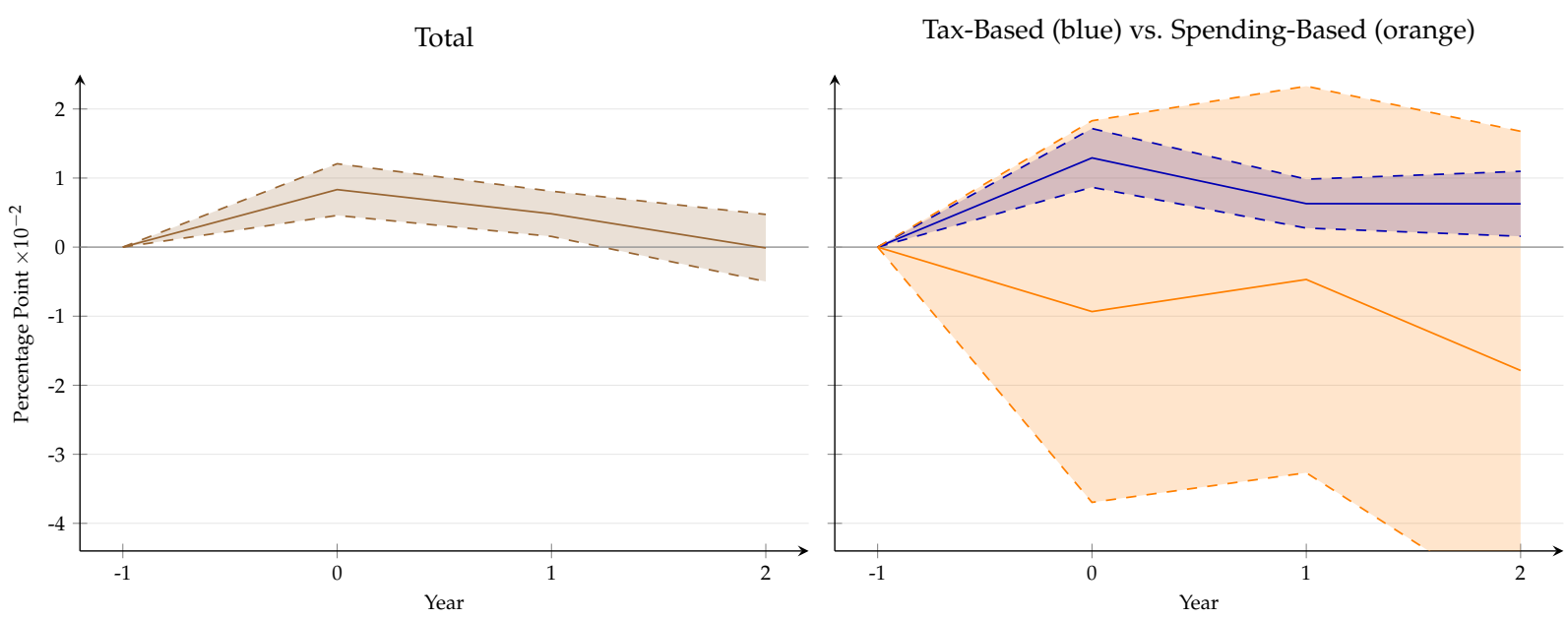

Note: The plain lines denote the cumulative response of the growth rate of the consumer confidence index to a fiscal shock, the shaded areas denote the $90 \%$ confidence interval.

Figure 10 reports the response of private investment to different types of fiscal shocks according to the relative level of labour informality in the economy. In countries with reduced informal sectors, the three types of consolidations have a recessionary impact from the year of implementation. As suggested in Ferrière and Navarro (2018), tax progressivity can potentially affect the fiscal multiplier, and it is a possible explanation to the results presented by Carrière-Swallow et al. (2018) which indicate that taxed-based consolidations could be significantly more recessionary in OECD countries than in LAC. If tax progressivity is higher in advanced economies, then the wealthiest agents are significantly less taxed in LAC than in OECD countries, even in relative terms. However, the negative response of private investment to tax-based consolidations in low informality countries in LAC allow to reject this possible explanation. In highly informal countries, spending-based consolidation lead to a hike in investment. However, the very large confidence interval and low number of observations impede to draw robust conclusions on this result. The tax-based multiplier appears to 
Figure 10 - Impact of Fiscal Consolidation on Investment: Low vs. High Informality
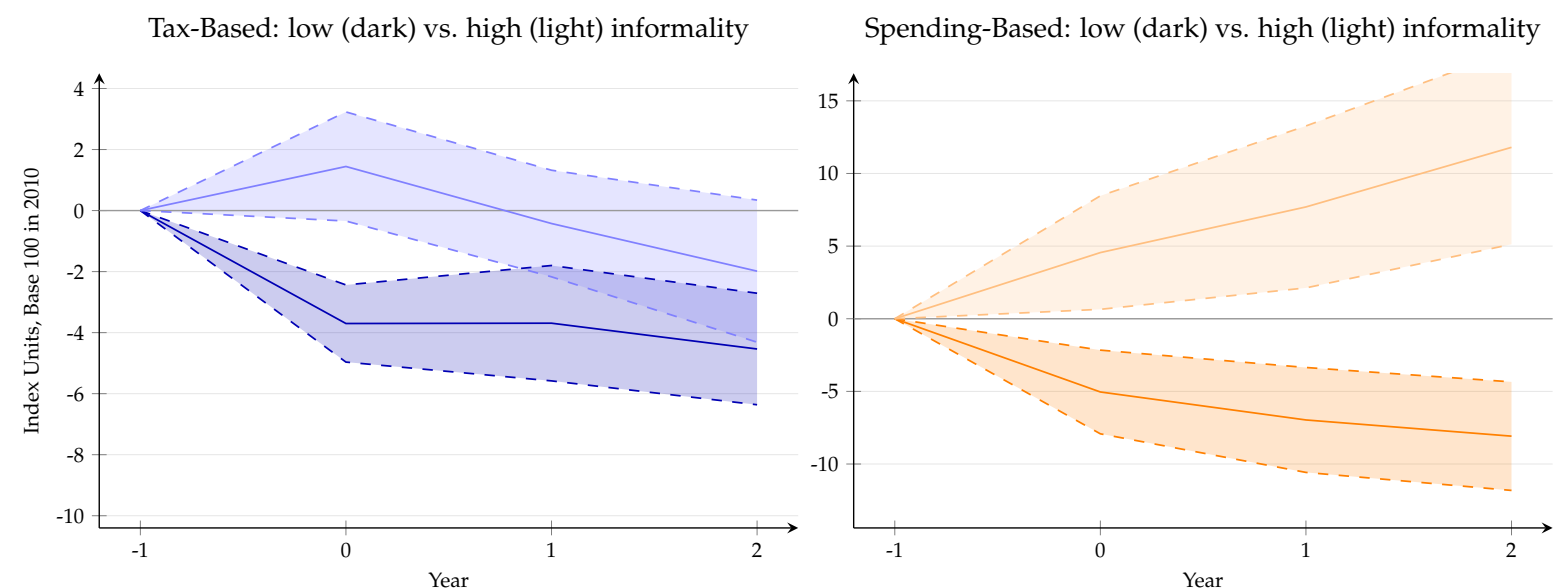

Total: low (dark) vs. high (light) informality

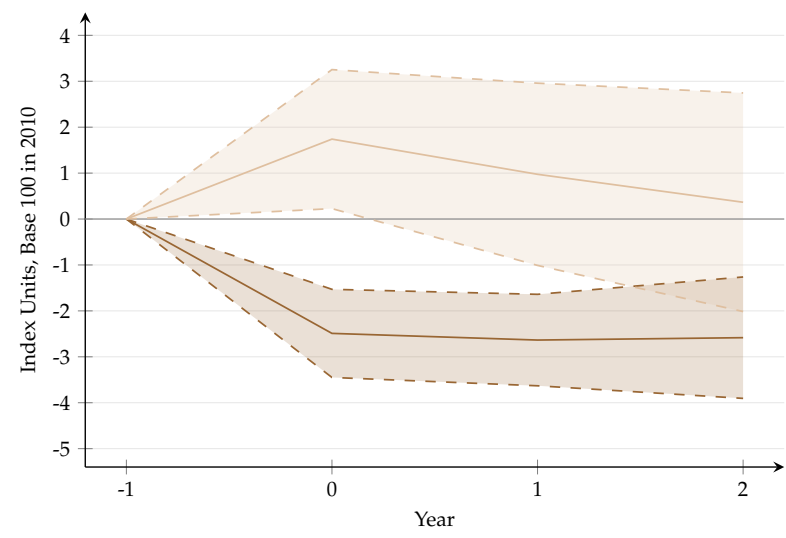

Note: The plain lines denote the cumulative response of investment to a fiscal shock, the shaded areas denote the $90 \%$ confidence interval.

be positively affected by informality, as such consolidations do not appear to lead to recessionary effects on investment after two years in highly informal economies.

Could positive effects on business confidence be driving this absence of recessionary impact in highly informal economies? Figure 11 does not provide any evidence that business confidence is affected by fiscal consolidations in LAC, although the data quality for this index does not allow to draw any robust conclusion. An alternative explanation that is compatible with the results presented in table 10 is that in highly informal economies, a relatively lower share of agents from the productive sector is affected by taxation hikes: in this context, the higher the level of informality, the lower the decline in investment following a fiscal consolidation.

Figure 12 reports the reaction of the labour market informality rate, according to the productive definition, to fiscal consolidations and evidences that labour informal- 
ity does not respond to total fiscal consolidations, neither in economies with reduced informal labour markets nor in economies in which this sector is larger. As predicted by the DSGE model in Pappa et al. (2015), the results indicate that the informal labour market shrinks after a spending-based consolidation, in both high and low informality economies. However, low data availability explains the large multiplier and confidence interval, and this result is not robust to a different measure of labour informality (corresponding to the legal definition). ${ }^{13}$ On the contrary, the results evidence that in high informality contexts, as predicted by Pappa et al. (2015), the informality rate responds positively to a tax-based consolidation and increases in approximately 5 percentage points after two years. As evidenced in figure 13, this increase in the labour informality rate is robust to using the legal definition of labour informality, despite a lower economic significance and a lower number of observations, especially for Guatemala (4 observations) and Jamaica (1 observation), two countries with large informal sectors.

Figure 11 - Impact of Fiscal Consolidation on Business Confidence in Countries With High Levels of Informality

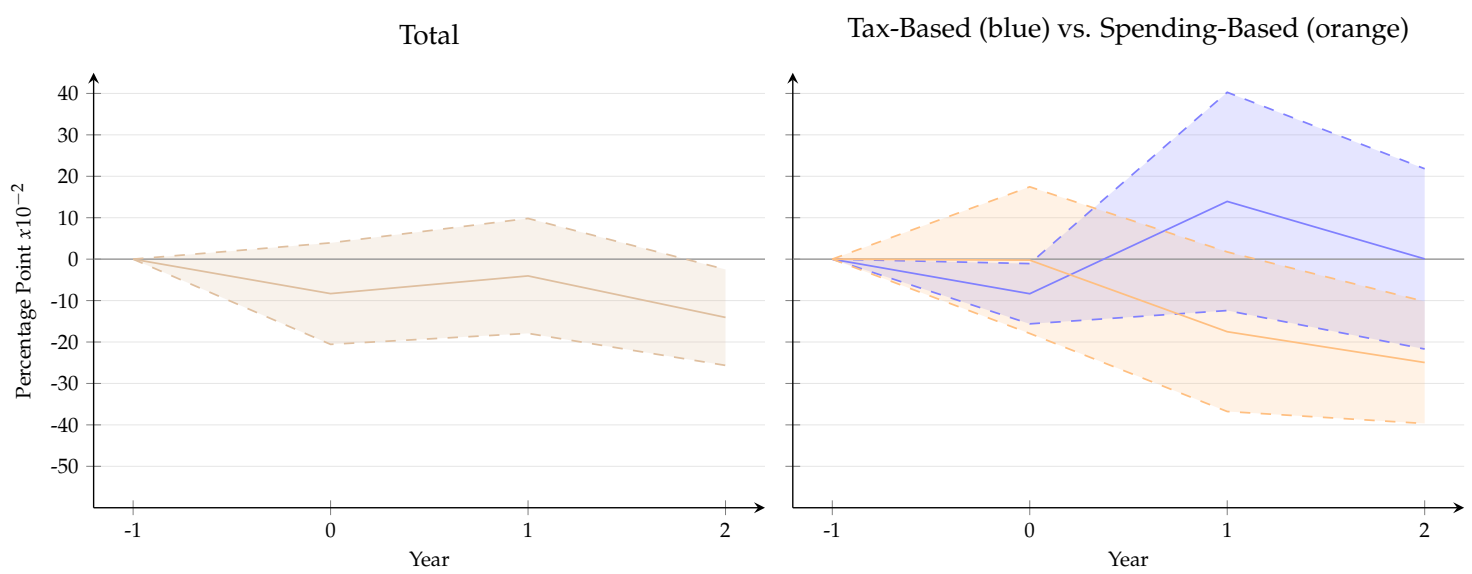

Note: The plain lines denote the cumulative response of the growth rate of the business confidence index to a fiscal shock, the shaded areas denote the $90 \%$ confidence interval. As the results are not significantly different from 0 for all levels of informality, they are only reported for highly informal countries. Results for countries with a low level of informality are available from the author upon request.

The positive response of the informality rate to tax-based fiscal consolidations supports the evidence on the initially null and subsequently negative effect on investment in high informality contexts: on the supply side, some formal employers might have chosen to become informal after a tax-based consolidation, and this tax evasion strategy would therefore represent a buffer against fiscal shocks in the short-term, as it

\footnotetext{
${ }^{13}$ Results are available from the author upon request.
} 
Tax-Based: low (dark) vs. high (light) informality

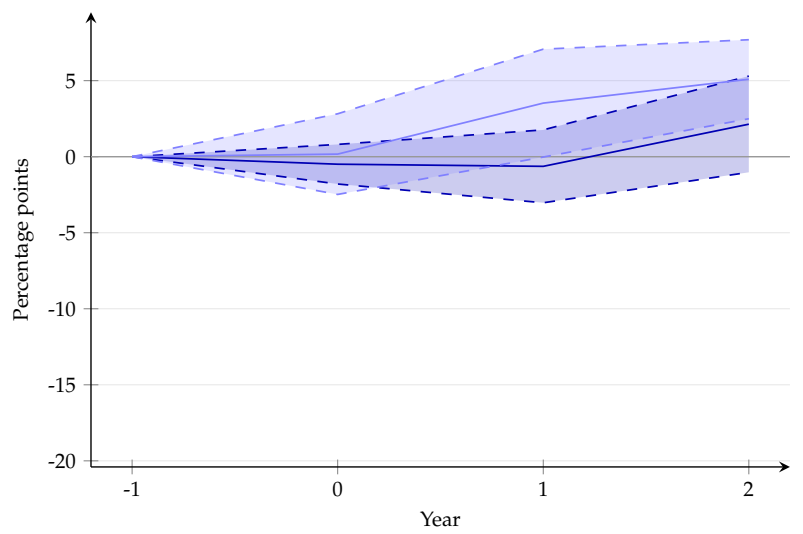

Spending-Based: low (dark) vs. high (light) informality

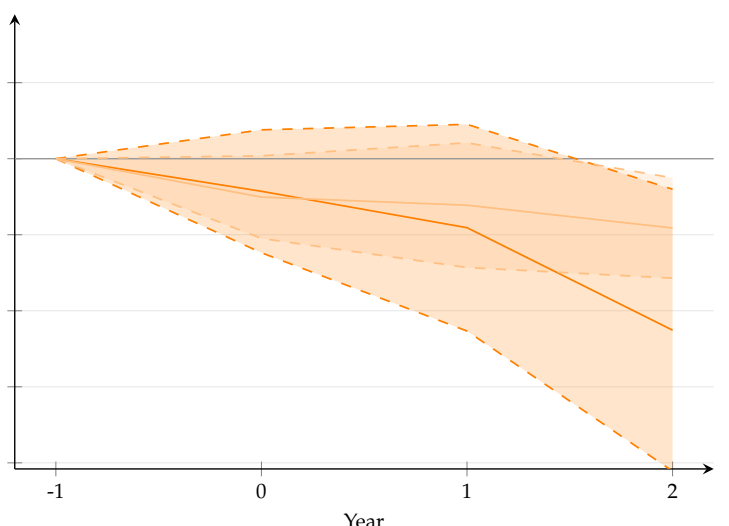

Total: low (dark) vs. high (light) informality

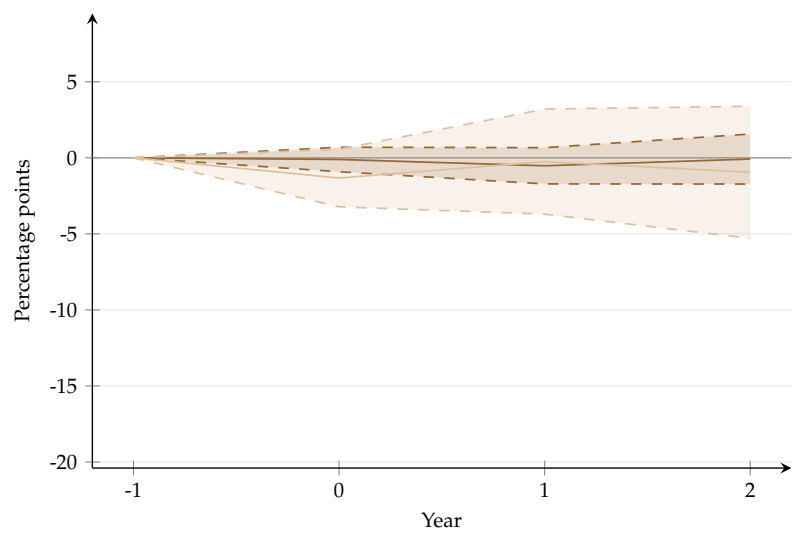

Note: The plain lines denote the cumulative response of informality (using the productive definition) to a fiscal shock, the shaded areas denote the $90 \%$ confidence interval. Driscoll and Kraay standard errors could not be computed for horizon $h=0$ and are therefore not presented. The results for horizons $h=1,2$ when Driscoll and Kraay standard errors are included do not lead to a different interpretation.

would allow some investment projects to remain feasible in spite of tax increases. However, the productivity of such firms would be expected to decline rapidly as the access to high quality public services and the financial sector, among others, would be limited. On the demand side, while dismissed workers become unemployed in advanced economies, they have the possibility to enter the informal labour market and earn a lower but positive salary in LAC and other emerging economies. This lower decline in income in LAC, in relative terms, could be associated with a lower decline in consumption, but results reported in figure 8 do not support this view. However, informal entrepreneurship is also an alternative to informal employment and unemployment for dismissed workers. In such a case, a fiscal consolidation is expected to lead to a 
Figure 13 - Impact of Fiscal Consolidation on Informality: Low vs. High Informality
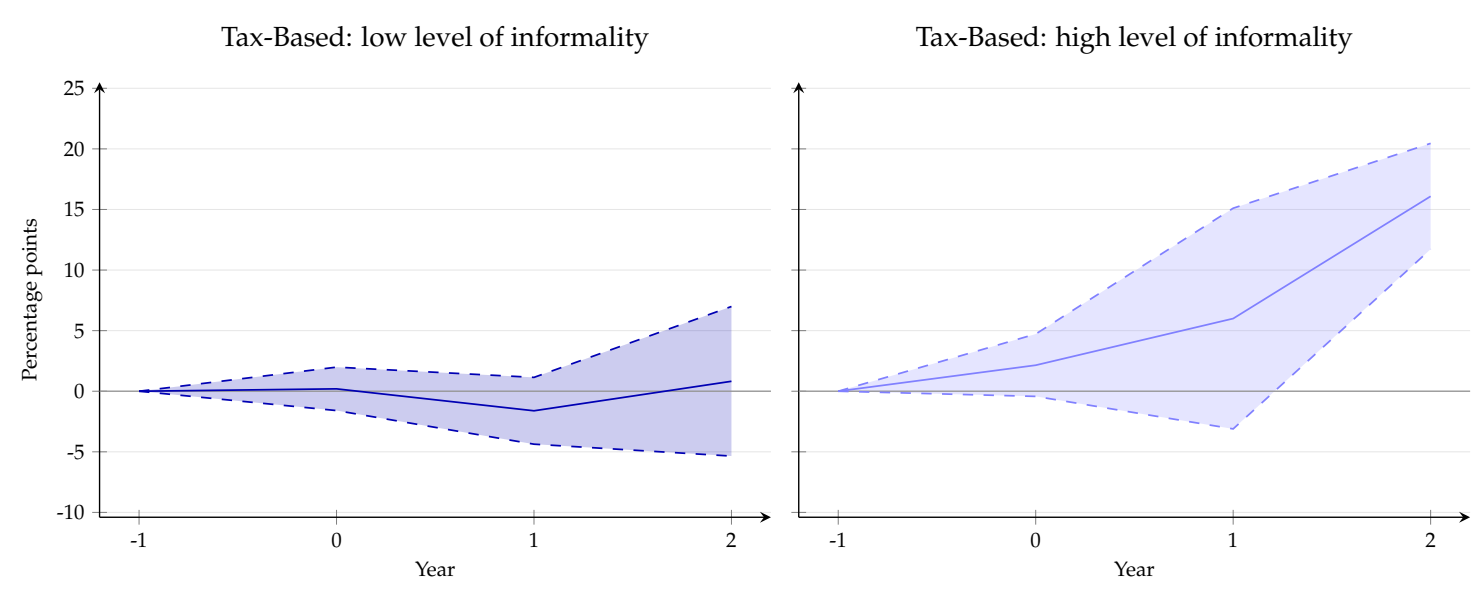

Note: The plain lines denote the cumulative response of informality (using the legal definition) to a fiscal shock, the shaded areas denote the $90 \%$ confidence interval.

short-term increase in investment that could at least partially compensate the negative effect on the formal sector: this mechanism is compatible with the observed response of investment to tax-based fiscal consolidation.

Because very few firms transition from the informal to the formal sector (La Porta and Shleifer, 2014), the reinforcement of the informality trap can represent a serious threat to already highly informal economies. This dynamics evidences the fact that the lower short-term effect of tax-based fiscal consolidations on output does come at a cost, which materializes in the medium- and long-term.

\section{Conclusion}

This paper extends a narrative dataset of fiscal consolidations in order to take into account differences in the credibility of the reforms and adds to a recent literature that uses this approach to identify the effect of fiscal consolidations on output in developing economies by finding a recessionary fiscal multiplier of 0.85 after two years, close to the level observed in advanced economies when the same methodology is used.

However, the findings also point towards differences between high income and emerging countries when decomposing between different types of consolidations: while the literature indicates that tax-based consolidations have a more recessionary impact than spending-based consolidations in advanced economies, this paper concludes that the two multipliers are not significantly different in LAC. Data availability restricts the interpretations that can be made about the spending-based fiscal multiplier, but this 
absence of difference between the two multipliers can be explained by the fact that the tax-based multiplier is affected by the presence of large informal labour markets. This result resists several robustness checks and additional controls for accompanying policies.

The findings of this paper support the view that labour market informality constitutes a social buffer in the short-term that allows to attenuate the effects of contractionary tax-based reforms by increasing investment opportunities through tax evasion, at the cost of declining productivity, and by providing dismissed workers with entrepreneurial alternatives to unemployment. The dataset only includes LAC countries, but these mechanisms are compatible with the economic system of many other lowand middle-income economies, and could therefore affect the conduct of macroeconomic policy beyond the region.

While this paper assesses the short-term impact of different types of fiscal consolidations, future empirical research could focus on the medium-term impact of such reforms, mainly on the budget deficit and the level of public debt. Deeper theoretical insight and further evidence using microeconomic data would also prove useful to test and identify more precisely the channels through which informality affects the conduct of macroeconomic policy. Finally, fiscal consolidations are likely to affect substantially income distribution: in a highly unequal region, a deeper understanding of these effects would allow to formulate better policy recommendations and limit the burden borne by the most vulnerable persons. 


\section{References}

AgÉnOR, P.-R. And P. J. Montiel (2008): Development Macroeconomics, Princeton University Press.

AÏT LAHCEN, M. (2020): “Informality, Frictional Markets and Monetary Policy,” Unpublished.

Alberola-Ila, E. AND C. URRUtia (2019): “Does Informality Facilitate Inflation Stability?" BIS Working Paper No. 778.

Alesina, A., O. Barbiero, C. Favero, F. Giavazzi, and M. Paradisi (2017): “The Effects of Fiscal Consolidations: Theory and Evidence," NBER Working Paper 23385.

Alesina, A., C. Favero, And F. Giavazzi (2018): “What do we Know About the Effects of Austerity?" NBER Working Paper 24246.

Alesina, A. AND R. Perotti (1997): “Fiscal Adjustments in OECD Countries: Composition and Macroeconomic Effect," Staff Papers, International Monetary Fund, 44.

Allingham, M. G. AND A. SAndmo (1972): “Income Tax Evasion: A Theoretical Analysis," Journal of Public Economics, 1, 323-338.

Amaglobeli, D., L. Jaramillo, P. Karnane, And A. ZdZienickA (2019): “Tax Reforms and Fiscal Shock Smoothing," IMF Working Paper 19/113.

ANGRIST, J. D. AND J.-S. PISCHKe (2008): Mostly Harmless Econometrics: An Empiricist's Companion, Princeton University Press.

ArdanaZ, M., M. HallerberG, And C. SCARTAscini (2019): “Fiscal Consolidations and Electoral Outcomes in Emerging Economies: Does the Policy Mix Matter? Macro and Micro Level Evidence from Latin America," IDB Working Papers Series No. 1002.

Arizala, F., J. R. GonZalez-Garcia, C. G. Tsangarides, And M. Yenice (2017): "The Impact of Fiscal Consolidations on Growth in Sub-Saharan Africa," IMF Working Paper No. 17/281.

Auerbach, A. J. AND Y. GorodnichenKo (2012): "Fiscal Multipliers in Recession and Expansion," in Fiscal Policy after the Financial Crisis, University of Chicago Press, 63-98.

Barry, F. AND M. B. Devereux (1995): “The 'Expansionary Fiscal Contraction' Hypothesis: A Neo-Keynesian Analysis," Oxford Economic Papers, 249-264. 
Batini, N., L. Eyraud, L. Forni, AND A. Weber (2014): “Fiscal Multipliers: Size, Determinants, and Use in Macroeconomic Projections," IMF Technical Notes and Manuals $14 / 04$.

Blanchard, O. AND R. Perotti (2002): “An Empirical Characterization of the Dynamic Effects of Changes in Government Spending and Taxes on Output," The Quarterly Journal of Economics, 117, 1329-1368.

Blanchard, O. J. AND D. LeIGH (2013): “Growth Forecast Errors and Fiscal Multipliers," American Economic Review, 103, 117-20.

BOYER, R. (2015): Économie politique des capitalismes, La Découverte.

Breuer, C. (2019): "Expansionary Austerity and Reverse Causality: A Critique of the Conventional Approach," INET Working Paper Series No. 98.

CARrière-Swallow, Y., A. C. DAVID, AND D. Leigh (2018): “The Macroeconomic Effects of Fiscal Consolidation in Emerging Economies: Evidence from Latin America," IMF Working Paper 18/142.

Chatelain, J.-B. And K. Ralf (2018): “Publish and Perish: Creative Destruction and Macroeconomic Theory," History of Economic Ideas, XXVI, 65-101.

Chen, C., E. DAbla-Norris, J. RAPPAPORT, And A. ZdZienickA (2019): “Political Costs of Tax-Based Consolidations," IMF Working Paper 19/298.

Cogan, J. F., J. B. TAYlor, V. Wieland, And M. H. Wolters (2013): “Fiscal Consolidation Strategy," Journal of Economic Dynamics and Control, 37, 404-421.

Cohen-Setton, J., E. Gornostay, And C. Ladreit (2019): “Aggregate Effects of Budget Stimulus: Evidence from the Large Fiscal Expansions Database," PIIE Working Paper No. 19-12.

Costa, C. J., A. C. G. Cintado, And C. U. IbÁÑEz (2017): “Fiscal Adjustments and the Shadow Economy in an Emerging Market," Presented at the International Conference on Regional Science International Trade and Employment, Sevilla.

DABLA-NORRIS, E. AND F. LIMA (2018): "Macroeconomic Effects of Tax Rate and Base Changes: Evidence from Fiscal Consolidations," IMF Working Paper No. 18/220.

DARVAS, Z. (2012): "Real Effective Exchange Rates for 178 Countries: A New Database," Working Paper 2012/06, Bruegel. 
DAvid, A. C., J. GuAJARdo, AND J. F. YÉPEZ (2019): “The Rewards of Fiscal Consolidation: Sovereign Spreads and Confidence Effects," IMF Working Paper No. 19/141.

DAvid, A. C. AND D. LeIGH (2018): “A New Action-based Dataset of Fiscal Consolidation in Latin America and the Caribbean," IMF Working Paper 18/94.

Dellas, H., D. Malliaropulos, D. Papageorgiou, And E. VourVachaKi (2017): “Fiscal Policy With an Informal Sector," Bank of Greece Working Paper, 235.

DeLong, J. B. And L. H. Summers (2012): “Fiscal Policy in a Depressed Economy," Brookings Papers on Economic Activity, 233-297.

Driscoll, J. C. AND A. C. KraAy (1998): “Consistent Covariance Matrix Estimation With Spatially Dependent Panel Data," Review of Economics and Statistics, 80, 549-560.

EKLOU, K. M. AND M. FALL (2020): “The (Subjective) Well-Being Cost of Fiscal Policy Shocks," IMF Working Paper 20/5.

FATÁs, A. AND L. H. Summers (2018): “The Permanent Effects of Fiscal Consolidations," Journal of International Economics, 112, 238-250.

FERrière, A. AND G. NAVARRo (2018): “The Heterogeneous Effects of Government Spending : It's All About Taxes," International Finance Discussion Papers 1237.

FURCERI, D. AND B. G. LI (2017): “The Macroeconomic (and Distributional) Effects of Public Investment in Developing Economies," IMF Working Paper 17/217.

Gruss, B. And S. KeBhaj (2019): “Commodity Terms of Trade: A New Database," IMF Working Paper 19/21.

Guajardo, J., D. Leigh, AND A. Pescatori (2014): “Expansionary Austerity: New International Evidence," Journal of the European Economic Association, 12, 949-968.

HogAN, V. (2004): “Expansionary Fiscal Contractions? Evidence from Panel Data," Scandinavian Journal of Economics, 106, 647-659.

Honda, J., H. MiyAmoto, And M. TAniguchi (2020): “Exploring the Output Effect of Fiscal Policy Shocks in Low Income Countries," IMF Working Paper 20/12.

HORY, M.-P. (2016): “Fiscal Multipliers in Emerging Market Economies: Can We Learn Something From Advanced Economies?" International Economics, 146, 59-84.

ILZetZKI, E. (2011): “Fiscal Policy and Debt Dynamics in Developing Countries," World Bank Policy Research Working Paper 5666. 
IlzetzKi, E., E. G. MendozA, And C. A. Végh (2013): “How Big (Small?) Are Fiscal Multipliers?" Journal of Monetary Economics, 60, 239-254.

Izquierdo, A., R. E. Lama, J. P. Medina, J. P. Puig, D. Riera-Crichton, C. A. VEGH, AND G. Vuletin (2019): "Is the Public Investment Multiplier Higher in Developing Countries? An Empirical Investigation," IMF Working Paper 19/289.

Jaramillo, F., M. GÓmez, AND A. GarcíA-SuAZA (2013): “Efecto de la política fiscal en un modelo de equilibrio general dinámico con sector informal: una aplicación para Colombia," Universidad del Rosario: Documentos de Trabajo, No. 139.

JORDÀ, Ò. (2005): “Estimation and Inference of Impulse Responses by Local Projections," American Economic Review, 95, 161-182.

JORDÀ, Ò. AND A. M. TAYlOR (2016): "The Time for Austerity: Estimating the Average Treatment Effect of Fiscal Policy," The Economic Journal, 126, 219-255.

KAHN, R. F. (1931): “The Relation of Home Investment to Unemployment," The Economic Journal, 41, 173-198.

Kalbhenn, A. And L. Stracca (2020): “Mad about Austerity? The Effect of Fiscal Consolidation on Public Opinion," Journal of Money, Credit and Banking.

KEynes, J. M. (1936): The General Theory of Employment, Interest and Money, London: Macmillan.

LA Porta, R. AND A. Shleifer (2014): “Informality and Development," Journal of Economic Perspectives, 28, 109-26.

Leigh, D., P. Devries, C. Freedman, J. Guajardo, D. Laxton, And A. PescaTORI (2010): “Will it Hurt? Macroeconomic Effects of Fiscal Consolidation," World Economic Outlook, 93, 124.

Miotti, E. L., C. Quenan, And E. T. Zane (2012): “Continuités et ruptures dans l'accumulation et la régulation en Amérique latine dans les années 2000: le cas de l'Argentine, du Brésil et du Chili," Revue de la régulation. Capitalisme, institutions, pouvoirs.

OECD, United NATIONs, CIAT, AND IDB (2019): Revenue Statistics in Latin America and the Caribbean 2019, OECD Publishing.

Pappa, E., R. SAjedi, And E. Vella (2015): “Fiscal Consolidation With Tax Evasion and Corruption," Journal of International Economics, 96, S56-S75. 
Romer, C. D. And D. H. Romer (2010): “The Macroeconomic Effects of Tax Changes: Estimates Based on a New Measure of Fiscal Shocks," American Economic Review, 100, 763-801.

Vegh, C. A. And G. Vuletin (2014): “The Road to Redemption: Policy Response to Crises in Latin America," IMF Economic Review, 62, 526-568.

YANG, W., J. FIDRMUC, AND S. GHOSH (2015): “Macroeconomic Effects of Fiscal Adjustment: A Tale of Two Approaches," Journal of International Money and Finance, 57, $31-60$. 


\section{Appendix}

\section{A Additional Tables}

Table A.1 - Data Definitions and Sources.

\begin{tabular}{|c|c|c|}
\hline Variable & Source & Definition \\
\hline Real GDP & WDI & $\begin{array}{l}\text { Log of real GDP in } 2010 \text { US Dol- } \\
\text { lars. }\end{array}$ \\
\hline $\begin{array}{l}\text { Real Private Invest- } \\
\text { ment and Consump- } \\
\text { tion }\end{array}$ & $\begin{array}{l}\text { WEO, elaborated by } \\
\text { the author }\end{array}$ & Base $100(2010)$ \\
\hline Informality 1 & $\begin{array}{l}\text { SEDLAC (CEDLAS } \\
\text { and The World Bank) }\end{array}$ & $\begin{array}{l}\text { Productive definition: share of } \\
\text { workers in informal jobs. }\end{array}$ \\
\hline Informality 2 & $\begin{array}{l}\text { SEDLAC (CEDLAS } \\
\text { and The World Bank) }\end{array}$ & $\begin{array}{l}\text { Legal definition: share of salaried } \\
\text { workers in informal jobs. }\end{array}$ \\
\hline $\begin{array}{l}\text { Narrative Fiscal Con- } \\
\text { solidation }\end{array}$ & $\begin{array}{l}\text { David and Leigh } \\
(2018)\end{array}$ & \\
\hline $\begin{array}{l}\text { Narrative Credibility } \\
\text { of Consolidation }\end{array}$ & $\begin{array}{l}\text { Elaborated by the au- } \\
\text { thor based on David } \\
\text { and Leigh }(2018)\end{array}$ & $\begin{array}{l}\text { Difference between consolidation } \\
\text { announcement and realization. }\end{array}$ \\
\hline $\begin{array}{l}\text { Commodity Export } \\
\text { Value }\end{array}$ & $\begin{array}{l}\text { Gruss and Kebhaj } \\
(2019)\end{array}$ & $\begin{array}{l}\text { Calculated using trade data on } 45 \\
\text { commodities. }\end{array}$ \\
\hline $\begin{array}{l}\text { Real Effective Ex- } \\
\text { change Rate }\end{array}$ & Darvas (2012) & $\begin{array}{l}\text { Base } 100(2007), 67 \text { trading part- } \\
\text { ners. }\end{array}$ \\
\hline Government Revenue & WDI & $\begin{array}{l}\text { Government revenue to GDP ratio } \\
\text { (excluding grants) }\end{array}$ \\
\hline
\end{tabular}


Table A.2 - Confidence Indexes Sources.

\begin{tabular}{|c|c|}
\hline Country & Source \\
\hline \multicolumn{2}{|l|}{ Business Confidence: } \\
\hline Argentina & Fundación Observatorio PyME \\
\hline Brazil & Confederação Nacional da Indústria \\
\hline Chile & Instituto Chileno de Administración Racional de Empresas \\
\hline Colombia & Fedesarrollo \\
\hline Costa Rica & $\begin{array}{l}\text { Unión Costarricense de Cámaras y Asociaciones del Sector } \\
\text { Empresarial Privado }\end{array}$ \\
\hline Dominican Republic & Banco Central de la República Dominicana \\
\hline Ecuador & Banco Central del Ecuador \\
\hline Guatemala & Banco de Guatemala \\
\hline Mexico & Instituto Nacional de Estadística, Geografía e Informática \\
\hline Peru & Banco Central de Reserva del Perú \\
\hline \multicolumn{2}{|l|}{ Consumer Confidence: } \\
\hline Argentina & Universidad Torcuato Di Tella \\
\hline Brazil & Confederação Nacional da Indústria \\
\hline Chile & Universidad del Desarrollo \\
\hline Colombia & Fedesarrollo \\
\hline Costa Rica & Universidad de Costa Rica \\
\hline Dominican Republic & Ministerio de Economía, Planificación y Desarrollo \\
\hline Ecuador & Banco Central del Ecuador \\
\hline Mexico & Instituto Nacional de Estadística, Geografía e Informática \\
\hline Uruguay & Universidad Católica del Uruguay \\
\hline
\end{tabular}

Table A.3 - Correlation Between Fiscal Consolidations and the Credibility Index

\begin{tabular}{|c|c|c|c|}
\hline \multirow[b]{2}{*}{ Fiscal consolidation: } & \multicolumn{3}{|c|}{ Credibility Index } \\
\hline & Total & Tax-Based & Spending-Based \\
\hline Total & -0.0468 & & \\
\hline Tax-Based & & 0.0808 & \\
\hline Spending-Based & & & 0.0823 \\
\hline Output growth: & 0.0316 & 0.0839 & -0.1927 \\
\hline
\end{tabular}


Figure A.1 - Correlation (OLS) Between Fiscal Consolidations and the Credibility Index

a. Total Fiscal Consolidation

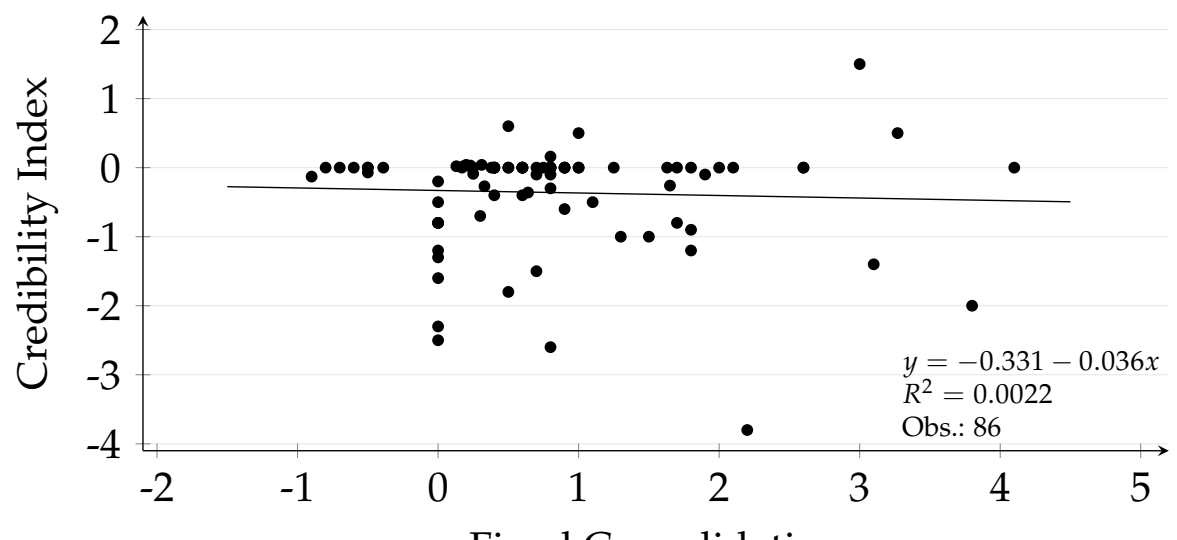

Fiscal Consolidation

b. Tax-Based Fiscal Consolidation

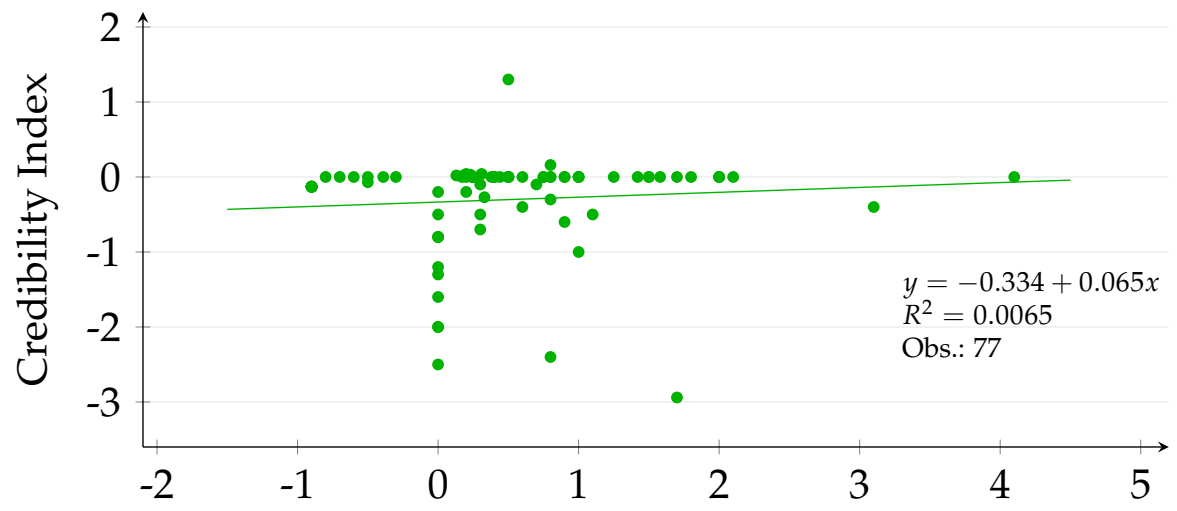

Fiscal Consolidation

c. Spending-Based Fiscal Consolidation

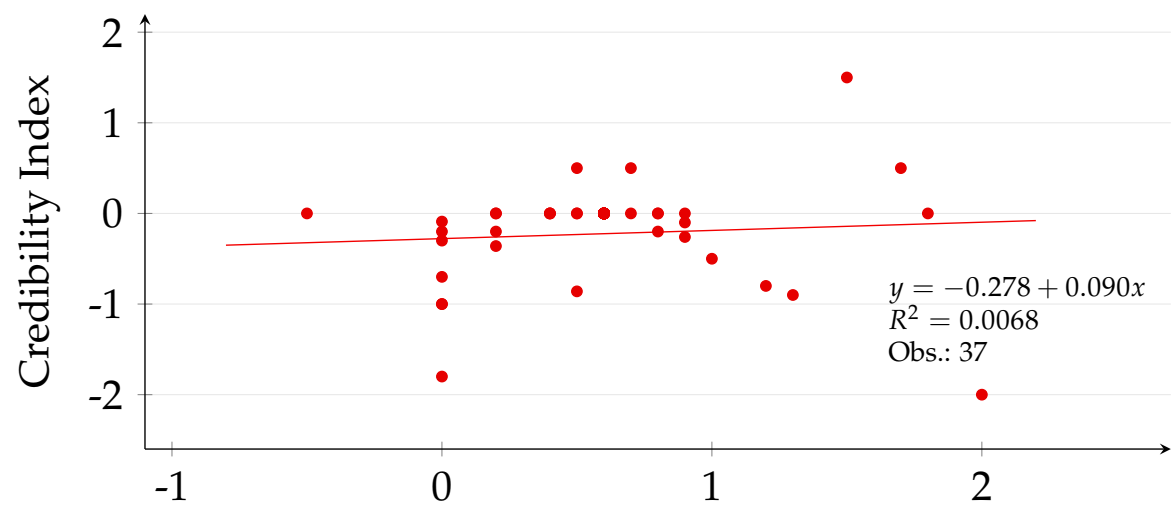

Fiscal Consolidation

Source: David and Leigh (2018) and the author, elaboration by the author. All units are expressed in percent of GDP. A negative value for the credibility index means that the implemented fiscal consolidation fell short of the announcement. 
Figure A.2 - Correlation (OLS) Between the Business Cycle and the Credibility Index

a. Total Fiscal Consolidation

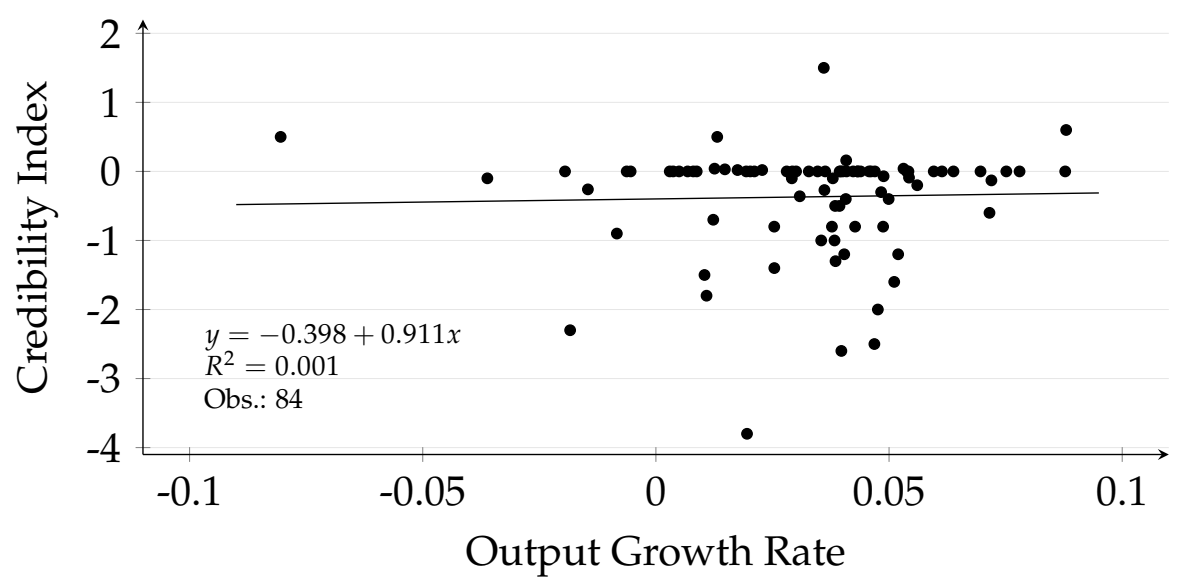

b. Tax-Based Fiscal Consolidation

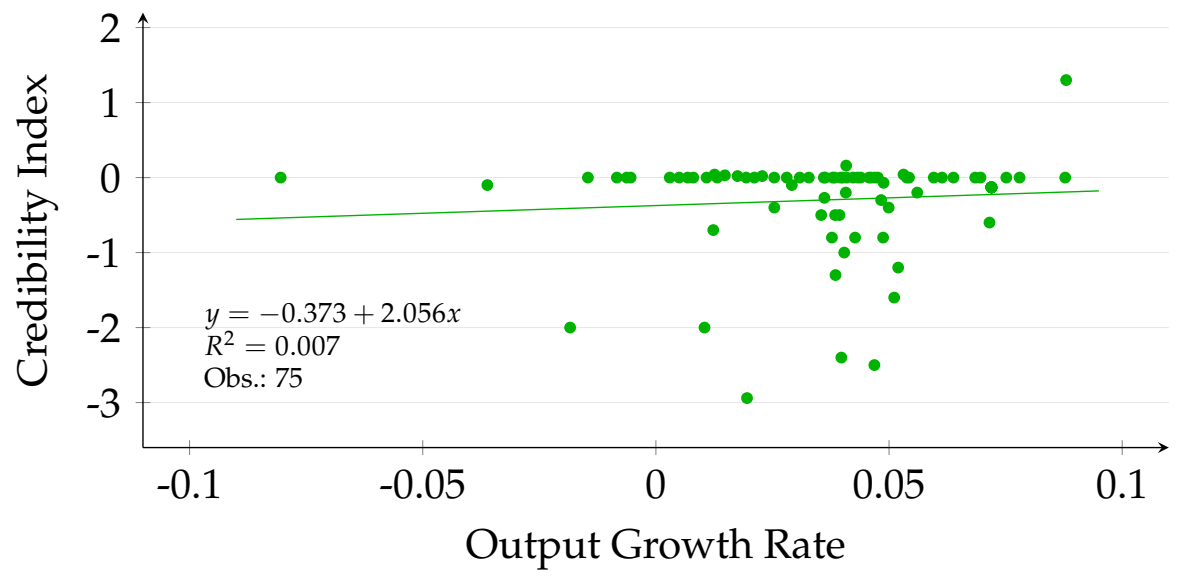

c. Spending-Based Fiscal Consolidation

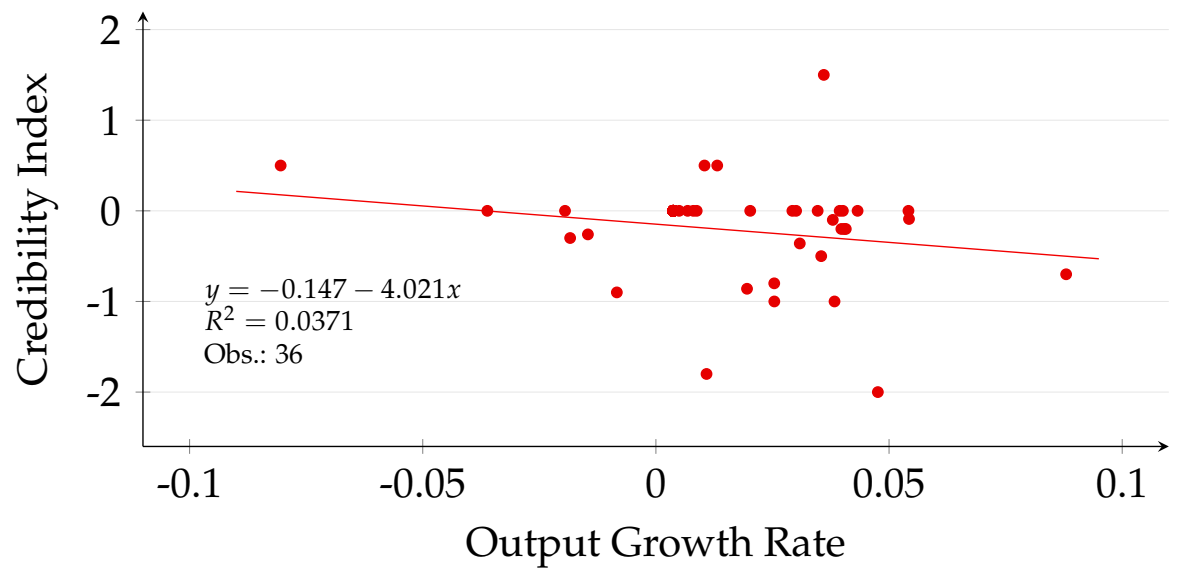

Source: David and Leigh (2018) and the author, elaboration by the author. Credibility index units are expressed in percent of GDP. A negative value for the credibility index means that the implemented fiscal consolidation fell short of the announcement. 


\section{B Credibility Index Construction}

This section provides the dataset of the credibility index to accompany the fiscal consolidation database elaborated by David and Leigh (2018). The construction of this dataset relies on several assumptions, as explained below.

The measure of the credibility of the reform provided in this dataset is an ex-post measure. Credibility is defined as the diference between the implemented measure of fiscal consolidation and the announced measure. Therefore, a 0 value for the credibility index corresponds to a fully credible reform, while a negative value indicates a lack of credibility of the measure (tax hikes or expenditure cuts were lower than announced). A positive value indicates that the reform went further than initially announced. The credibility index is expressed in terms of percent of GDP.

Relying on the hypothesis that anticipations matter for the outcome of the economic policy, the partial implementation of an announced reform, or an unimplemented announcement, can affect the economy. As an example, a fiscal consolidation amounting to 1 percent of GDP that was announced and fully implemented might lead to different economic outcomes than a 1 percent of GDP fiscal consolidation that was initially announced to amount to 3 percent of GDP. While this dataset does not allow to test this hypothesis, due to remaining endogeneity issues, it allows to control for this potential effect of credibility associated with the reform.

The main source used to build this datased is the database and the annexes provided in David and Leigh (2018). This source is sometimes complemented by the budget laws, IMF country reports and other national documents that it cites. These complementary documents are consulted only if the primary source is not self-sufficient to compute the announcement of the fiscal consolidation and therefore the difference with the implemented measures. For example, it is the case when the likely budget impact of the original annoucement is not explicitly mentionned.

By construction, the decision to implement a fiscal consolidation plan is not driven by prospective economic conditions in the database provided by David and Leigh (2018). However, the implementation of the announced measures might be, and therefore the estimate of the impact of the credibility of the reform on GDP growth and other variables might be biased due to endogeneity. For this reason, this dataset cannot be used to evaluate the effect of the credibility of fiscal consolidation plans, but it can be used to include a control variable and therefore improve the identification strategy to evaluate the impact of implemented measures of fiscal consolidation.

When David and Leigh (2018) identify the annoucement of a fiscal consolidation that is independent from prospective economic conditions but which was not implemented, the authors explicitly state that this fiscal consolidation episode does not appear in their database. However, this is a valuable quantitative information that is likely to partly explain the economic impact of fiscal consolidations. Therefore, as an official anouncement is made, it is included in the dataset provided in this paper, as well as the difference between this annoucement and the realization, the later being equal to zero in such a case.

When no element explicitly states that the implemented measure has been different from the announcement, what has been implemented is supposed to correspond to what has been announced and the credibility index takes the value of O. Similarly, when the sources do not indicate that a target is explicitly set, the announcement is 
supposed notto differ from the implemented measure, and the credibility index takes the value of $\mathrm{O}$.

As information is available for year 2017 in Chile, it is included in this datased, as well as in the fiscal consolidation database provided by David and Leigh (2018). In order not to bias the results, a missing value is assigned to all other countries in 2017 for both the fiscal consolidation and credibility index.

Below, I provide a detailed explanation of the construction of the credibility index for each country and each year. This description is based on, and must be acompanied by, the description provided in section III in David and Leigh (2018).

\section{B.1 Argentina}

\section{Argentina 1996:}

As the implemented fiscal consolidation corresponds to the announcement, the credibility index takes the value of 0 percent of GDP. The 1 percent of GDP consolidation plan announced in 1996 was fully implemented in that year ( 0.25 percent of GDP) and the following one ( 0.75 percent of GDP), and the mix between tax hikes and expenditure cuts was unaltered.

\section{Argentina 1997:}

As the implemented fiscal consolidation corresponds to the announcement made in 1996, the credibility index takes the value of 0 percent of GDP. See previous entry for 1996.

\section{Argentina 2016:}

The announced 2 percent of GDP tax hikes and 0.3 percent of GDP expenditure cuts were totally offset. The credibility index takes a total value of -2.3 percent of GDP, decomposed in a $\mathbf{- 2}$ percent of GDP value for the tax index and a $\mathbf{- 0 . 3}$ percent of GDP value for the spending index. The announced measures were offset by tax cuts and spending increases that were not primarily motivated by cyclical fluctuations attenuation, but instead by long-term considerations, such as pension spending. As the budget remained largely unchanged, this announced measure is therefore not included in the fiscal consolidation dataset, but the announcement appears in the credibility dataset.

\section{B.2 Bolivia}

\section{Bolivia 1995:}

As the implemented fiscal consolidation corresponds to the announcement, the credibility index takes the value of 0 percent of GDP. The 1.2 percent of GDP tax increase was fully implemented and was partially offset by a 0.3 percent of GDP increase in 
expenditures, which was lower than expected. The net effect is 0.9 percent of GDP, and the lower than anticipated increase in spending does not affect the credibility of the fiscal consolidation.

\section{Bolivia 2004:}

As the implemented fiscal consolidation corresponds to the announcement, the credibility index takes the value of 0 percent of GDP. The 2 percent of GDP tax hikes announced in 2004 were fully implemented.

\section{Bolivia 2005:}

As the implemented fiscal consolidation corresponds to the announcement, the credibility index takes the value of 0 percent of GDP. The 4.1 percent of GDP tax hikes announced for 2005, some of them following a referendum conducted in July 2004, were fully implemented.

\section{B.3 Brazil}

\section{Brazil 2004:}

The announced 0.2 percent of GDP tax hikes were not implemented. The credibility index takes a total value of $\mathbf{- 0 . 2}$ percent of GDP, corresponding to a $\mathbf{- 0 . 2}$ percent of GDP value for the tax index. The 0.7 percent of GDP tax hikes that were implemented in 2004 to reduce the deficit and increase efficiency but were accompanied by tax exemptions amounting to 0.5 percent of GDP. The 0.2 percent of GDP net measure was more than offset by a 0.5 percent of GDP increase in public spending.

\section{Brazil 2015:}

The announced 0.5 percent of GDP expenditure cuts and 0.4 percent of GDP tax hikes were partially offset by a later 0.1 percent of GDP tax cut. The credibility index takes a total value of $\mathbf{- 0 . 1}$ percent of GDP, corresponding to a $\mathbf{- 0 . 1}$ percent of GDP value for the tax index. The 0.4 percent of GDP tax hikes in 2015 were partially offset by the adoption of a 0.1 percent of GDP increase in tax exemptions.

\section{B.4 Chile}

\section{Chile 1990:}

As the implemented fiscal consolidation corresponds to the announcement, the credibility index takes the value of 0 percent of GDP. The 1.5 percent of GDP tax hikes 
announced for 1990 and the 0.5 percent of GDP tax hikes announced for 1991 were fully implemented but $2 / 3$ of these additional resources were destined to increase social expenditure. Therefore, the 0.5 percent of GDP tax hikes that were not offset in 1990 correspond to the announcement.

\section{Chile 1991:}

As the implemented fiscal consolidation corresponds to the announcement made in 1990, the credibility index takes the value of 0 percent of GDP. See previous entry for 1990.

\section{Chile 2003:}

As the implemented fiscal consolidation corresponds to the announcement, the credibility index takes the value of 0 percent of GDP. The 0.4 percent of GDP spending cuts and the 0.2 percent of GDP tax hikes announced for 2003 were fully implemented.

\section{Chile 2004:}

As the implemented fiscal consolidation corresponds to the announcement, the credibility index takes the value of 0 percent of GDP. The fiscal consolidation initiated in 2003 continued in 2004 and the announced 0.4 percent of GDP tax increase for that year were fully implemented.

\section{Chile 2008:}

As the implemented fiscal expansion corresponds to the announcement, the credibility index takes the value of 0 percent of GDP. The 0.5 percent of GDP reduction in the structural balance target announced in 2007 was fully implemented in 2008.

\section{Chile 2014:}

As tax hikes were more important than initially announced in a multi-year fiscal plan, the credibility index takes the value of +0.02 percent of GDP, decomposed in $a+0.02$ percent of GDP value for the tax index and a 0 percent of GDP value for the spending index. A tax reform was announced in 2014 for the period 2014-2018 with tax hikes amounting to a total of 3 percent of GDP, but one measure amounting to 0.8 percent of GDP would only be implemented in 2018. Therefore, the total announcement for years 2014 to 2017 amounts to 2.2 percent of GDP.

The Informe Financiero de la Reforma Tributaria, published in 2014, estimates the impact of the reforms to amount to 0.29 percent of GDP in 2014, 0.53 percent of GDP in 2015, 0.94 percent of GDP in 2016 and 0.68 percent of GDP in 2017 (as well as 0.73 
percent of GDP in 2018). However, the 2015 Informe de Finanzas Públicas indicates that the tax reforms in 2014 amounted to 0.38 percent of GDP. Therefore, the total effect of the reform amounts to 2.53 percent of GDP over the period 2014-2017, a 15\% increase compared to the initial announcement of 2.2 percent of GDP.

Consequently, the detailed announcement for years 2014 to 2017, amounting to 2.2 percent of GDP, corresponds to $87 \%$ of the implemented measures. As the exogenous motivation accounts for one third of the consolidation plan, the announced measures amount to 0.11 percent of GDP in 2014, 0.16 percent of GDP in 2015, 0.27 percent of GDP in 2016 and 0.2 percent of GDP in 2017. As the implemented tax hikes amounted to 0.13 percent of GDP in 2014 (i.e. $1 / 3$ of 0.38 percent of GDP), the tax and total credibility indexes take a value of 0.02 percent of GDP

\section{Chile 2015:}

As implemented tax hikes were greater than initially announced, the credibility index takes the value of +0.02 percent of GDP, decomposed in a +0.02 percent of GDP value for the tax index and a 0 percent of GDP value for the spending index. Tax hikes for exogenous reasons amounted to 0.18 percend of GDP, a 0.02 percent of GDP increase with respect to the initial announcement. See previous entry for 2014.

\section{Chile 2016:}

As implemented tax hikes were greater than initially announced, the credibility index takes the value of +0.04 percent of GDP, decomposed in a +0.04 percent of GDP value for the tax index and a 0 percent of GDP value for the spending index. Tax hikes for exogenous reasons amounted to 0.31 percend of GDP, a 0.04 percent of GDP increase with respect to the initial announcement. See previous entry for 2014.

\section{Chile 2017:}

As implemented tax hikes were greater than initially announced, the credibility index takes the value of +0.03 percent of GDP, decomposed in a +0.03 percent of GDP value for the tax index and a 0 percent of GDP value for the spending index. Tax hikes for exogenous reasons amounted to 0.23 percend of GDP ( $1 / 3$ of 0.68 percent of GDP), a 0.03 percent of GDP increase with respect to the initial announcement. See previous entry for 2014.

\section{B.5 Colombia}

\section{Colombia 1993:}

Announced tax hikes were more than offset by increased expenditures, but as the source could not be consulted, the credibility index takes a missing value, and the 
same is true for the tax index and the spending index. Neither the details for the announced measures nor for the implementation could be consulted.

\section{Colombia 1996:}

Tax hikes were announced in late 1995 but were more than offset by increased expenditures, and as the source could not be consulted, the credibility index takes a missing value. The same is true for the tax index and the spending index. Neither the details for the announced measures nor for the implementation could be consulted.

\section{Colombia 2000:}

As the implemented fiscal consolidation plan does not explicitly divert from the announcement, the credibility index takes the value of 0 percent of GDP. No clear objective is indicated. Therefore, by assumption, the announcement is consequent with the implementation.

\section{Colombia 2003:}

As the announced fiscal consolidation plan was partially offset, the credibility index takes the value of $\mathbf{- 0 . 5}$ percent of GDP, decomposed in a -0.5 percent of GDP value for the tax index and a 0 percent of GDP value for the spending index. Announced tax hikes amounting to 1.6 percent of GDP were partially offset by increased expenditures amounting to 0.5 percent of GDP. As the net tax hikes are indicated in the database and the spending-based consolidation takes the value of 0 , the expenditure credibility index is not affected.

\section{Colombia 2004:}

As the announced fiscal consolidation plan was fully offset, the credibility index takes the value of $\mathbf{- 1 . 2}$ percent of GDP, decomposed in a -1.2 percent of GDP value for the tax index and a 0 percent of GDP value for the spending index. Tax hikes amounting to 1.2 percent of GDP were announced in 2003 and were expected to be implemented in 2004, but they were fully offset by increased expenditures.

\section{Colombia 2011:}

As the implemented fiscal consolidation corresponds to the announcement made at the end of 2010, the credibility index takes the value of 0 percent of GDP. The 0.4 percent of GDP tax hikes announced and approved in 2010 were fully implemented in 2011. 


\section{Colombia 2012:}

As the implemented fiscal consolidation corresponds to the announcement made at the end of 2010, the credibility index takes the value of 0 percent of GDP. Tax hikes amounting to 0.8 percent of GDP were announced and approved in 2010 and fully implemented in 2012.

\section{Colombia 2015:}

As the implemented fiscal consolidation corresponds to the announcement, the credibility index takes the value of 0 percent of GDP. Expenditure cuts amounting to 0.5 percent of GDP were announced as part of a multi-year plan and were fully implemented.

\section{Colombia 2016:}

As the implemented fiscal consolidation corresponds to the announcement, the credibility index takes the value of 0 percent of GDP. Expenditure cuts amounting to 0.7 percent of GDP were announced and fully implemented.

\section{B.6 Costa Rica}

\section{Costa Rica 1990:}

As a multi-year fiscal consolidation plan was partially implemented, the credibility index takes the value of -1.0 percent of GDP, decomposed in a 0 percent of GDP value for the tax index and a $\mathbf{- 1 . 0}$ percent of GDP value for the spending index. A fiscal consolidation plan was announced in 1990 for the year 1990 and 1991. Measures included tax hikes amounting to 3 percent of GDP and expenditure cuts amounting to 2 percent of GDP. Tax hikes were fully implemented and amounted to 1.5 percent of GDP in each year, while expenditure cuts were not implemented, nor in 1990 (1 percent of GDP) neither in 1991 (1 percent of GDP).

\section{Costa Rica 1991:}

As measures announced in 1990 were partially implemented and new measures in 1991 were delayed and also partially implemented, the credibility index takes the value of -1.4 percent of GDP, decomposed in a -0.4 percent of GDP value for the tax index and a -1.0 percent of GDP value for the spending index. Expenditure cuts amounting to 1 percent of GDP were announced in 1990 for year 1991 and not implemented (see previous entry for 1990). Tax hikes announced both in 1990 and 1991 were implemented but some were delayed, leading to a 0.4 percent of GDP loss in revenue with repect to what had been announced. 


\section{Costa Rica 1992:}

As revenue increase exceeded what had been planned and expenditure cuts were not implemented, the credibility index takes the value of +0.6 percent of GDP, decomposed in a +1.3 percent of GDP value for the tax index and a -0.7 percent of GDP value for the spending index. Expenditure cuts amounting to 0.7 percent of GDP were announced but not implemented. On a net basis, revenue measures led to a 1.3 percent of GDP higher yield than what had been programmed.

\section{Costa Rica 1993:}

As tax measures were fully implemented but source documents concerning expenditure cuts could not be consulted, the total credibility index and the spending index take missing values while the tax index takes the value of 0 percent of GDP. tax measures announced in 1992 and 1993 amounted in a 0.3 percent of GDP drop in revenues on a net basis and were fully implemented. Revenue measures were announced in 1993 but not implemented. As the source documents could not be consulted, the total and spending credibility index take a missing value.

\section{Costa Rica 1994:}

As the implemented fiscal plan corresponds to the announcement, the credibility index takes the value of 0 percent of GDP. Tax cuts amounting to 0.5 percent of GDP were announced in 1992 and fully implemented in 1994.

\section{Costa Rica 1995:}

As announced fiscal consolidation reforms were delayed and not fully implemented, the credibility index takes the value of -1.2 percent of GDP, decomposed in a -1.0 percent of GDP value for the tax index and a $\mathbf{- 0 . 2}$ percent of GDP value for the spending index. Announcements in 1995 indicate tax hikes amounting to 2 percent of GDP for that year and 1 percent of GDP in 1996, as well as expenditure cuts amounting to 1 percent of GDP for 1995. However, tax hikes were delayed and only amounted to 1 percent of GDP, while effective expenditure cuts also fell short of the announcement, amounting to 0.8 percent of GDP.

\section{Costa Rica 1996:}

As tax hikes announced in 1995 were partially offset by increased expenditure, the credibility index takes the value of -0.7 percent of GDP, decomposed in a -0.7 percent of GDP value for the tax index and a 0 percent of GDP value for the spending index. 1 percent of GDP tax hikes, announced in 1995 for year 1996, were partly offset by a 0.7 percent of GDP increase in expenditure. 


\section{Costa Rica 1997:}

As the implemented fiscal plan corresponds to the announcement, the credibility index takes the value of 0 percent of GDP. Tax hikes were fully offset by the unwinding of temporary past increases in taxes, without affecting the credibility index. Expending cuts amounting to 0.4 percent of GDP were announced and fully implemented.

\section{Costa Rica 2012:}

As the approved fiscal consolidation plan was not implemented, the credibility index takes the value of -2.5 percent of GDP, decomposed in a -2.5 percent of GDP value for the tax index and a 0 percent of GDP value for the spending index. A fiscal consolidation consisting in tax hikes amounting to 2.5 percent of GDP was presented to the National Assembly in 2011 and approved in 2012, but it was voided by the Supreme Court later in the same year.

\section{Costa Rica 2016:}

As the announced fiscal consolidation plan was not supported by the Congress and therefore only partially implemented, the credibility index takes the value of -0.4 percent of GDP, decomposed in a $\mathbf{- 0 . 2}$ percent of GDP value for the tax index and a -0.2 percent of GDP value for the spending index. Announced tax hikes and expenditure cuts amounted each to 0.4 percent of GDP. Measures implemented fell short of the announcement after the Congress denied support and consisted in tax hikes and expenditure cuts amounting each to 0.2 percent of GDP.

\section{B.7 Dominican Republic}

\section{Dominican Republic 1995:}

An announced fiscal consolidation plan was fully offset, but the sources could not be consulted. Therefore, the credibility index takes a missing value, and the same is true for the tax index and the spending index. Neither the details for the announced measures nor for the implementation could be consulted.

\section{Dominican Republic 2004:}

As announced expenditure cuts were not fully implemented, the credibility index takes the value of -0.8 percent of GDP, decomposed in a 0 percent of GDP value for the tax index and a $\mathbf{- 0 . 8}$ percent of GDP value for the spending index. Tax hikes amounting to 0.5 percent of GDP were fully implemented, but expenditure cuts amounting to 1.2 percent of GDP fell short of the announced target of 2 percent of GDP. 
Dominican Republic 2006:

As the implemented fiscal plan corresponds to the announcement, the credibility index takes the value of 0 percent of GDP. The fiscal plan led to a 0.8 percent of GDP net decline in revenues. No element indicates that the implementation differs from the announcement.

\section{Dominican Republic 2007:}

As the announced fiscal consolidation plan was not fully implemented, the credibility index takes the value of $\mathbf{- 0 . 6}$ percent of GDP, decomposed in a $\mathbf{- 0 . 6}$ percent of GDP value for the tax index and a 0 percent of GDP value for the spending index. Tax hikes yielded 0.9 percent of GDP of additional revenues, falling short of the package that was announced and approved by the Congress, and which was expected to increase revenues in 1.5 percent of GDP.

Dominican Republic 2011:

As the announced fiscal consolidation plan was not fully implemented, the credibility index takes the value of $\mathbf{- 0 . 3 6}$ percent of GDP, decomposed in a 0 percent of GDP value for the tax index and a $\mathbf{- 0 . 3 6}$ percent of GDP value for the spending index. An overall fiscal consolidation plan amounting to 1 percent of GDP was announced for 2011, including tax hikes of 0.44 percent of GDP, which were effectively Implemented. Therefore, the announced expenditure cuts amount to 0.56 percent of GDP, but implemented measures only led to a 0.2 percent of GDP decline in spending.

\section{Dominican Republic 2013:}

As the announced fiscal consolidation plan was partially offset, the credibility index takes the value of -2.0 percent of GDP, decomposed in a 0 percent of GDP value for the tax index and a -2.0 percent of GDP value for the spending index. Tax hikes amounting to 1.8 percent of GDP were announced, approved by Congress and fully implemented. Announced expenditure cuts that were expected to generate savings of 4 percent of GDP were partially offset by a 2 percent of GDP increase in other expenditures.

\section{B.8 Ecuador}

\section{Ecuador 1990:}

As the announced fiscal consolidation plan was blocked and only partially implemented, the credibility index takes the value of -0.27 percent of GDP, decomposed in a -0.27 percent of GDP value for the tax index and a 0 percent of GDP value for the spending index. Tax measures amounting to 0.6 percent of GDP on a net basis were 
announced but later blocked by the Congress. Implemented measures amount to 0.33 percent of GDP, falling short of the announcement.

\section{Ecuador 1993:}

As the announced fiscal consolidation plan was only partially implemented, the credibility index takes the value of -3.8 percent of GDP, decomposed in a -2.94 percent of GDP value for the tax index and a -0.86 percent of GDP value for the spending index. Fiscal measures amounting to 6 percent of GDP were announced in 1993, but no information is available on the distribution between tax hikes and expenditure cuts. Tax hikes amounted to 1.7 percent of GDP and expenditure cuts represented 0.5 percent of GDP. The total fiscal consolidation plan for 1993 therefore amounted to 2.2 percent of GDP, i.e. $36.67 \%$ of the announcement. By assumption, the difference between the announcement and the implementation is proportionnally the same for revenue and spending measures.

\section{Ecuador 2000:}

As the announced fiscal consolidation plan was only partially implemented, the credibility index takes the value of $\mathbf{- 1 . 8}$ percent of GDP, decomposed in a 0 percent of GDP value for the tax index and a -1.8 percent of GDP value for the spending index. Tax hikes amounting to 1.3 percent of GDP were announced and implemented. Expenditure cuts amounting to 1 percent of GDP on a net basis were announced but more than offset by other expenditure increases. The net effect of expenditure measures amounted to an increase in 0.8 percent of GDP.

\section{Ecuador 2001:}

As the announced fiscal consolidation plan was reversed, the credibility index takes the value of -0.5 percent of GDP, decomposed in a -0.5 percent of GDP value for the tax index and a 0 percent of GDP value for the spending index. The tax hikes amounting to 0.5 percent of GDP were reversed by the constitutional tribunal.

\section{Ecuador 2008:}

As the announced tax hikes were implemented and fully offset by acompanying increases in expenditure, the credibility index takes the value of 0 percent of GDP. Tax hikes amounted to 0.6 percent of GDP and aimed to increase the tax to GDP ratio. As acompanying increases in expenditures did not prevent this objective to be met, the credibility index takes the value of 0 percent of GDP. 


\section{B.9 Guatemala}

Guatemala 1993:

As the announced fiscal consolidation plan was fully offset, the credibility index takes the value of $\mathbf{- 1 . 3}$ percent of GDP, decomposed in a -1.3 percent of GDP value for the tax index and a 0 percent of GDP value for the spending index. Tax hikes amounting to 1.3 percent of GDP were announced but fully offset by expenditures hikes.

\section{Guatemala 1995:}

As the announced fiscal consolidation plan was partly blocked, the credibility index takes the value of -0.3 percent of GDP, decomposed in a -0.3 percent of GDP value for the tax index and a 0 percent of GDP value for the spending index. Compensation measures yielded 0.8 percent of GDP of additional revenues, falling short of the 1.1 percent of GDP consolidation plan that was announced.

\section{Guatemala 1996:}

As the implemented tax hikes fell short of the multi-year fiscal consolidation plan, the credibility index takes the value of -0.1 percent of GDP, decomposed in a -0.1 percent of GDP value for the tax index and a 0 percent of GDP value for the spending index. A new administration took office in 1996 and announced tax hikes amounting to 4.0 percent of GDP over the period 1996 - 2000, i.e. 0.8 percent of GDP per year during the period. However, tax hikes implemented in 1996 amounted to 0.7 percent of GDP.

\section{Guatemala 1997:}

As no tax hikes were implemented while a multi-year fiscal consolidation plan had been announced, the credibility index takes the value of -0.8 percent of GDP, decomposed in a -0.8 percent of GDP value for the tax index and a 0 percent of GDP value for the spending index. See previous entry for 1996.

\section{Guatemala 1998:}

As no tax hikes were implemented while a multi-year fiscal consolidation plan had been announced, the credibility index takes the value of -0.8 percent of GDP, decomposed in a $\mathbf{- 0 . 8}$ percent of GDP value for the tax index and a 0 percent of GDP value for the spending index. See previous entry for 1996. 


\section{Guatemala 1999:}

As no tax hikes were implemented while a multi-year fiscal consolidation plan had been announced, the credibility index takes the value of -0.8 percent of GDP, decomposed in a $\mathbf{- 0 . 8}$ percent of GDP value for the tax index and a 0 percent of GDP value for the spending index. See previous entry for 1996.

\section{Guatemala 2000:}

As tax hikes fell short of the anounced measures in a multi-year fiscal consolidation plan and expenditure cuts were lower than initially announced, the credibility index takes the value of $\mathbf{- 1 . 0}$ percent of GDP, decomposed in a $\mathbf{- 0 . 5}$ percent of GDP value for the tax index and a $\mathbf{- 0 . 5}$ percent of GDP value for the spending index. See previous entry for 1996. Tax hikes amounting to 0.3 of GDP were approved and implemented in 2000, falling short of the 0.8 tax hikes announced in 1996. Expenditure cuts amounting to 1.5 percent of GDP were announced but partially offset by an increase in current expenditures amounting to 0.5 percent of GDP.

\section{Guatemala 2002:}

As the announced expenditure cuts were not fully implemented, the credibility index takes the value of -0.1 percent of GDP, decomposed in a 0 percent of GDP value for the tax index and a $\mathbf{- 0 . 1}$ percent of GDP value for the spending index. Tax hikes amounting to 1 percent of GDP were announced and implemented. Expenditure cuts amounting to 1 percent of GDP were announced but only partially implemented, as they represented 0.9 percent of GDP.

\section{Guatemala 2012:}

As the implemented fiscal consolidation corresponds to the announcement, the credibility index takes the value of 0 percent of GDP. The 0.4 percent of GDP expenditure cuts announced in 2012 were fully implemented.

\section{Guatemala 2013:}

As the implemented fiscal consolidation corresponds to the announcement, the credibility index takes the value of 0 percent of GDP. The 1 percent of GDP tax hikes announced in 2013 were fully implemented. 


\section{B.10 Jamaica}

Jamaica 1992:

As the implemented fiscal consolidation corresponds to the announcement, the credibility index takes the value of 0 percent of GDP. The 2.1 percent of GDP tax hikes announced in 1991 were fully implemented in 1992.

\section{Jamaica 1999:}

As revenues increased due to cyclical factors instead of the effects of the announced tax hikes, and because the decline in expenditures exceeds the announced measures, the credibility index takes the value of -1.5 percent of GDP, decomposed in a -2 percent of GDP value for the tax index and a +0.5 percent of GDP value for the spending index. Tax hikes amounting to 2 percent of GDP were announced in 1999, but the increase in revenue was primarily driven by cyclical and temporary factors. As there is no tax-based fiscal consolidation recorded for that year while a 2 percent of GDP tax hikes were announced, the credibility index for revenue measures takes a value of 2 percent of GDP. Announced expenditure cuts corresponding to 0.2 percent of GDP were fully implemented and additional, unannounced measures were also adopted. As primary current expenditures fell by 1.1 percent of GDP and capital expenditure increased by 0.4 percent of GDP, and because the spending-based fiscal consolidation takes the net value of 0.7 percent of GDP in the database, the credibility index for expenditure measures takes a value of +0.5 percent of GDP.

Jamaica 2000:

As no quantitative measure of the fiscal consolidation announcement is available, the credibility index takes the value of 0 percent of GDP. By asumption, the implemented measures correspond to the announcement.

Jamaica 2003:

As the implemented tax hikes corresponds to the announcement and unannounced spending cuts were implemented, the credibility index takes the value of +1.5 percent of GDP, decomposed in a 0 percent of GDP value for the tax index and a +1.5 percent of GDP value for the spending index. Tax hikes increased revenues by 1.5 percent of GDP in 2003 and 0.5 percent of GDP in 2004. Additionally, unannounced primary expenditure cuts amounting to 2 percent of GDP were implemented in 2003 (1.5 percent of GDP) and 2004 (0.5 percent of GDP). 
Jamaica 2004:

As the implemented tax hikes corresponds to the announcement made in 2003 and the unannounced expenditure cuts approved in 2003 were partly implemented in 2004 , the credibility index takes the value of +0.5 percent of GDP, decomposed in a 0 percent of GDP value for the tax index and a +0.5 percent of GDP value for the spending index. See previous entry for 2003.

\section{Jamaica 2012:}

As the implemented fiscal consolidation corresponds to the announcement, the credibility index takes the value of 0 percent of GDP. The 1.6 percent of GDP tax hikes were fully implemented in 2012 and 2013 (0.8 percent of GDP in both years).

\section{Jamaica 2013:}

As the implemented fiscal consolidation corresponds to the announcement, the credibility index takes the value of 0 percent of GDP. The second half of the 1.6 percent of GDP tax hikes announced in 2012 was fully implemented in 2013 (0.8 percent of GDP). Furthermore, a new consolidation plan, consisting in tax hikes accounting for 1.6 percent of GDP and spending cuts amounting to 0.6 percent of GDP, was announced and fully implemented in 2013 (75\%) and 2014 (25\%), the mix between tax hikes and expenditure cuts remaining unaltered.

Jamaica 2014:

As the implemented fiscal consolidation corresponds to the announcement, the credibility index takes the value of 0 percent of GDP. The remaining $25 \%$ of the 1.6 percent of GDP tax hikes and the 0.8 percent of GDP expenditure cuts announced in 2013 were fully implemented in 2014.

\section{B.11 Mexico}

\section{Mexico 1989:}

As the implemented fiscal consolidation corresponds to the announcement, the credibility index takes the value of 0 percent of GDP. The 0.9 percent of GDP tax hikes announced for 1989 were fully implemented in that year.

\section{Mexico 2010:}

The announced 1 percent of GDP tax hikes were only partially implemented. The credibility index takes a total value of -0.4 percent of GDP, corresponding to a -0.4 
percent of GDP value for the tax index. The tax hikes implemented in 2010 raised non-oil revenues by 0.6 percent of GDP, i.e. represented approximately $2 / 3$ of the announced reform.

\section{Mexico 2014:}

As the implemented fiscal consolidation corresponds to the announcement, the credibility index takes the value of 0 percent of GDP. The 0.6 percent of GDP tax hikes approved in 2013 were fully implemented in 2014.

\section{B.12 Paraguay}

\section{Paraguay 1989:}

As the implemented tax hikes corresponds to the announcement and as no anouncement is explicitly mentionned regarding the expenditure cuts that were implemented, the credibility index takes the value of 0 percent of GDP. The 2 percent of GDP tax hikes were announced and implemented. As no announcement is recorded concerning the net 0.6 percent of GDP expenditure cuts, by assumption, the implemented measures correspond to the anouncement and the credibility index takes a value of 0 .

Paraguay 2001:

As the implemented tax hikes corresponds to the announcement and the announced expenditure cuts were partly implemented, the credibility index takes the value of -0.9 percent of GDP, decomposed in a 0 percent of GDP value for the tax index and a $\mathbf{- 0 . 9}$ percent of GDP value for the spending index. Expenditure cuts amounting to 2.2 percent of GDP were announced, as well as tax hikes reaching 0.5 percent of GDP. While no element suggest that tax measures fell short of the announcement, the expenditure reduction reached only 1.3 percent of GDP.

Paraguay 2003:

As the implemented fiscal consolidation corresponds to the announcement, the credibility index takes the value of 0 percent of GDP. The 1.5 percent of GDP tax hikes were fully implemented in 2003 (1.25 percent of GDP) and in 2004 (0.25 percent of GDP).

Paraguay 2004:

While measures adopted in 2003 were fully implemented in 2004, new announcement were made but the new measures were only partly implemented. Therefore, 
the credibility index takes the value of -2.6 percent of GDP, decomposed in a -2.4 percent of GDP value for the tax index and a $\mathbf{- 0 . 2}$ percent of GDP value for the spending index. The 0.25 percent of GDP tax hike approved in 2003 was fully implemented in 2004 and two tax measures increased revenues in a total of 0.45 percent of GDP. Broad reforms comprised tax hikes announcement and were approved by the congress, with a yield expected at 2.5 percent of GDP. However, they were postponed several times and yielded only 0.1 percent of GDP of additional revenue. Expenditure cuts of 0.2 percent of GDP were also announced but amended by the Congress and therefore not implemented. The total announcement represented 3.4 percent of GDP, corresponding to 3.2 percent of GDP tax hikes and 0.2 percent of GDP expenditure cuts. Implemented measures amounted to a total of 0.8 percent of GDP, with 0.8 percent of GDP tax hikes and 0 percent of GDP expenditure cuts.

Paraguay 2005:

As the implemented fiscal measures corresponds to the announcement made in 2004, the credibility index takes the value of 0 percent of GDP. Two tax cuts had a negative effect on revenues amounting to -0.6 percent of GDP.

Paraguay 2006:

As the implemented fiscal measures corresponds to the announcement made in 2004, the credibility index takes the value of 0 percent of GDP. A tax cuts had a negative effect on revenues amounting to -0.7 percent of GDP.

Paraguay 2014:

As the implemented fiscal consolidation corresponds to the announcement made in 2013, the credibility index takes the value of 0 percent of GDP. Announced tax hikes amount to 0.24 percent of GDP.

Paraguay 2016:

As the implemented fiscal consolidation corresponds to the announcement, the credibility index takes the value of 0 percent of GDP. The 1.1 percent of GDP reduction in primary expense was partly offset by a 0.3 expense increase, but no element indicates that the later measure was unannounced. Therefore, by assumption, the announcement corresponds to the implemented measures. 


\section{B.13 Peru}

\section{Peru 1992:}

As the implemented fiscal consolidation corresponds to the announcement made in 1991, the credibility index takes the value of 0 percent of GDP. Tax hikes of 1 percent of GDP were approved in 1991 and implemented in 1992.

\section{Peru 1993:}

As the tax reform was fully offset by increased expenditures, the credibility index takes the value of $\mathbf{- 1 . 6}$ percent of GDP, decomposed in a $\mathbf{- 1 . 6}$ percent of GDP value for the tax index and a 0 percent of GDP value for the spending index. As the tax reform, adopted in the context of a stabilization program, was fully implemented but acompanied by increased expenditures, it is not included in the dataset. However, as the announcement of a fiscal consolidation measure was made, the credibility index is equal to the additive inverse of the estimated revenue yield of the measure.

\section{Peru 2002:}

As the tax hikes adopted in 2002 and implemented in 2002 and 2003 outperformed the announcement by $25 \%$, the total and tax credibility indexes take the value of $\mathbf{+ 0 . 0 4}$ percent of GDP. The initial expected yield of 0.8 percent of GDP was overachieved by $25 \%$, at 1 percent of GDP. The implemented measures yielded additional revenues amounting to 0.2 percent of GDP in 2002 and 0.8 percent of GDP in 2003. By hypothesis, the outperformance is equally devided into the two years. The credibility (total and tax) indexes take the value of +0.04 (i.e. $0.25 \times 0.2$ ) in 2002 and +0.16 (i.e. $0.25 \times 0.8)$ in 2003 .

\section{Peru 2003:}

As the tax hikes adopted in 2002 and implemented in 2002 and 2003 outperformed the announcement by $25 \%$, the total and tax credibility indexes take the value of $+\mathbf{0 . 1 6}$ percent of GDP. See previous entry for 2002 .

\section{Peru 2011:}

As the implemented fiscal consolidation corresponds to the announcement, the credibility index takes the value of 0 percent of GDP. The net effect of tax reforms was a 0.39 percent of GDP drop in revenues in 2011, as well as a 0.38 percent of GDP increase in revenues in 2012 Several reforms had opposite effects, but by assumption, the implementation of the plan does not differ from the announcement. 
Peru 2012:

As the implemented fiscal consolidation corresponds to the announcement made in 2011, the credibility index takes the value of 0 percent of GDP. See previous entry for 2011.

\section{B.14 Uruguay}

\section{Uruguay 1990:}

As the implemented fiscal consolidation corresponds to the announcement, the credibility index takes the value of 0 percent of GDP. Tax hikes amounting to 1.7 percent of GDP were announced and fully implemented.

\section{Uruguay 1995:}

As the announced fiscal consolidation plan was partially offset, the credibility index takes the value of $\mathbf{- 0 . 2 6}$ percent of GDP, decomposed in a 0 percent of GDP value for the tax index and a $\mathbf{- 0 . 2 6}$ percent of GDP value for the spending index. A fiscal consolidation plan amounting to 2.25 percent of GDP was designed and approved in 1995 for that year and 1996. The plan comprised both tax and expenditure measures. Tax hikes amounting to 1 percent of GDP were announced and fully implemented that year $(75 \%)$ and in 1996 (25\%). Expenditure cuts amounting to 1.25 percent of GDP were also announced for 1995, but the measures were partially offset and fell short of the announcement, at 0.9 percent of GDP in 1995 and 0 percent of GDP in 1996. The spending credibility index therefore takes the value of -0.35 percent of GDP, of which $75 \%$ is assigned to year 1995 and 25\% is assigned to year 1996

\section{Uruguay 1996:}

As the announced fiscal consolidation plan was partially offset, the credibility index takes the value of $\mathbf{- 0 . 0 9}$ percent of GDP, decomposed in a 0 percent of GDP value for the tax index and a $\mathbf{- 0 . 0 9}$ percent of GDP value for the spending index. See previous entry for 1995.

\section{Uruguay 2000:}

As the implemented fiscal consolidation corresponds to the announcement, the credibility index takes the value of 0 percent of GDP. Expenditure cuts amounting to 0.8 percent of GDP were announced and fully implemented. 
Uruguay 2002:

As the implemented fiscal consolidation plan was greater than what was announced, the credibility index takes the value of +0.5 percent of GDP, decomposed in a 0 percent of GDP value for the tax index and a +0.5 percent of GDP value for the spending index. A multi-year fiscal consolidation plan was approved in 2002. Tax hikes were consistent with the announcement and amounted to 1.2 percent of GDP in 2002, while expenditure cuts were more important than initially announced, at 1.7 percent of GDP (spending measures amounting to 1.2 percent of GDP had been announced).

\section{Uruguay 2003:}

As the implemented fiscal consolidation corresponds to the announcement made in 2002 and 2003, the credibility index takes the value of 0 percent of GDP. Tax hikes were approved in 2002 and implemented in 2003, while new expenditure cuts were approved and fully implemented in 2003.

\section{Uruguay 2004:}

Because the removal of temporary revenue measures was more important than initially announced, the credibility index takes the value of -0.07 percent of GDP, decomposed in a -0.07 percent of GDP value for the tax index and a 0 percent of GDP value for the spending index. Temporary revenue measures approved in 2002 were effectively removed in 2004 and 2005. The removal of these measures was estimated to amount to 1.2 percent of GDP in 2002, but it finally amounted to 1.4 percent of GDP (0.5 percent of GDP in 2004 and 0.9 percent of GDP in 2005). The difference between the announcement and the implementation, 0.2 percent of GDP, follows the same distribution for the years 2004 (-0.07 percent of GDP) and 2005 (-0.13 percent of GDP).

Uruguay 2005:

Because the removal of temporary revenue measures was more important than initially announced, the credibility index takes the value of -0.13 percent of GDP, decomposed in a $\mathbf{- 0 . 1 3}$ percent of GDP value for the tax index and a 0 percent of GDP value for the spending index. See previous entry for 2004.

\section{Uruguay 2015:}

As the implemented fiscal consolidation corresponds to the announcement, the credibility index takes the value of 0 percent of GDP. Expenditure cuts amounting to 0.6 percent of GDP were announced and fully implemented. 
Table B.1 - Announcement and Credibility of Narrative Fiscal Shocks (\% of GDP)

\begin{tabular}{|c|c|c|c|c|c|c|c|}
\hline \multirow[b]{2}{*}{ Country } & \multirow[b]{2}{*}{ Year } & \multicolumn{3}{|c|}{ Announcement } & \multicolumn{3}{|c|}{ Credibility } \\
\hline & & Total & Tax & Spend & Total & Tax & Spend \\
\hline ARG & 1996 & 0.25 & 0.25 & 0.00 & 0.00 & 0.00 & 0.00 \\
\hline ARG & 1997 & 0.75 & 0.75 & 0.00 & 0.00 & 0.00 & 0.00 \\
\hline ARG & 2016 & 2.30 & 2.00 & 0.30 & -2.30 & -2.00 & -0.30 \\
\hline BOL & 1995 & 0.90 & 0.90 & 0.00 & 0.00 & 0.00 & 0.00 \\
\hline BOL & 2004 & 2.00 & 2.00 & 0.00 & 0.00 & 0.00 & 0.00 \\
\hline BOL & 2005 & 4.10 & 4.10 & 0.00 & 0.00 & 0.00 & 0.00 \\
\hline BRA & 2004 & 0.10 & 0.10 & 0.00 & -0.10 & -0.10 & 0.00 \\
\hline BRA & 2015 & 0.90 & 0.40 & 0.50 & -0.10 & -0.10 & 0.00 \\
\hline CHL & 1990 & 0.50 & 0.50 & 0.00 & 0.00 & 0.00 & 0.00 \\
\hline CHL & 1991 & 0.17 & 0.17 & 0.00 & 0.00 & 0.00 & 0.00 \\
\hline CHL & 2003 & 0.60 & 0.20 & 0.40 & 0.00 & 0.00 & 0.00 \\
\hline CHL & 2004 & 0.40 & 0.40 & 0.00 & 0.00 & 0.00 & 0.00 \\
\hline CHL & 2008 & -0.50 & 0.00 & -0.50 & 0.00 & 0.00 & 0.00 \\
\hline CHL & 2014 & 0.11 & 0.11 & 0.00 & 0.02 & 0.02 & 0.00 \\
\hline CHL & 2015 & 0.16 & 0.16 & 0.00 & 0.02 & 0.02 & 0.00 \\
\hline CHL & 2016 & 0.27 & 0.27 & 0.00 & 0.04 & 0.04 & 0.00 \\
\hline CHL & 2017 & 0.20 & 0.20 & 0.00 & 0.03 & 0.03 & 0.00 \\
\hline COL & 1993 & . & • & 0.00 & . & $\cdot$ & 0.00 \\
\hline $\mathrm{COL}$ & 1996 & . & . & 0.00 & . & . & 0.00 \\
\hline $\mathrm{COL}$ & 2000 & 0.90 & 0.00 & 0.90 & 0.00 & 0.00 & 0.00 \\
\hline $\mathrm{COL}$ & 2003 & 1.60 & 1.60 & 0.00 & -0.50 & -0.50 & 0.00 \\
\hline $\mathrm{COL}$ & 2004 & 1.20 & 1.20 & 0.00 & -1.20 & -1.20 & 0.00 \\
\hline COL & 2011 & 0.40 & 0.40 & 0.00 & 0.00 & 0.00 & 0.00 \\
\hline $\mathrm{COL}$ & 2012 & 0.80 & 0.80 & 0.00 & 0.00 & 0.00 & 0.00 \\
\hline $\mathrm{COL}$ & 2015 & 0.50 & 0.00 & 0.50 & 0.00 & 0.00 & 0.00 \\
\hline COL & 2016 & 0.70 & 0.00 & 0.70 & 0.00 & 0.00 & 0.00 \\
\hline CRI & 1990 & 2.50 & 1.50 & 1.00 & -1.00 & 0.00 & -1.00 \\
\hline CRI & 1991 & 4.50 & 3.50 & 1.00 & -1.40 & -0.40 & -1.00 \\
\hline CRI & 1992 & -0.10 & -0.80 & 0.70 & 0.60 & 1.30 & -0.70 \\
\hline CRI & 1993 & . & -0.30 & & & 0.00 & \\
\hline CRI & 1994 & -0.50 & -0.50 & 0.00 & 0.00 & 0.00 & 0.00 \\
\hline
\end{tabular}

\section{Continued on next page}


Table B.1 - continued from previous page

\begin{tabular}{|c|c|c|c|c|c|c|c|}
\hline \multirow[b]{2}{*}{ Country } & \multirow[b]{2}{*}{ Year } & \multicolumn{3}{|c|}{ Announcement } & \multicolumn{3}{|c|}{ Credibility } \\
\hline & & Total & Tax & Spend & Total & Tax & Spend \\
\hline CRI & 1995 & 3.00 & 2.00 & 1.00 & -1.20 & -1.00 & -0.20 \\
\hline CRI & 1996 & 1.00 & 1.00 & 0.00 & -0.70 & -0.70 & 0.00 \\
\hline CRI & 1997 & 0.40 & 0.00 & 0.40 & 0.00 & 0.00 & 0.00 \\
\hline CRI & 2012 & 2.50 & 2.50 & 0.00 & -2.50 & -2.50 & 0.00 \\
\hline CRI & 2016 & 0.80 & 0.40 & 0.40 & -0.40 & -0.20 & -0.20 \\
\hline DOM & 1995 & . & & 0.00 & & & 0.00 \\
\hline DOM & 2004 & 2.50 & 0.50 & 2.00 & -0.80 & 0.00 & -0.80 \\
\hline DOM & 2006 & -0.80 & -0.80 & 0.00 & 0.00 & 0.00 & 0.00 \\
\hline DOM & 2007 & 1.50 & 1.50 & 0.00 & -0.60 & -0.60 & 0.00 \\
\hline DOM & 2011 & 1.00 & 0.44 & 0.56 & -0.36 & 0.00 & -0.36 \\
\hline DOM & 2013 & 5.80 & 1.80 & 4.00 & -2.00 & 0.00 & -2.00 \\
\hline ECU & 1990 & 0.60 & 0.60 & 0.00 & -0.27 & -0.27 & 0.00 \\
\hline $\mathrm{ECU}$ & 1993 & 6.00 & 4.64 & 1.36 & -3.80 & -2.94 & -0.86 \\
\hline $\mathrm{ECU}$ & 2000 & 0.70 & 0.50 & 0.20 & -0.20 & 0.00 & -0.20 \\
\hline ECU & 2001 & 0.50 & 0.50 & 0.00 & -0.50 & -0.50 & 0.00 \\
\hline $\mathrm{ECU}$ & 2008 & 0.00 & 0.00 & 0.00 & 0.00 & 0.00 & 0.00 \\
\hline GTM & 1993 & 1.30 & 1.30 & 0.00 & -1.30 & -1.30 & 0.00 \\
\hline GTM & 1995 & 1.10 & 1.10 & 0.00 & -0.30 & -0.30 & 0.00 \\
\hline GTM & 1996 & 0.80 & 0.80 & 0.00 & -0.10 & -0.10 & 0.00 \\
\hline GTM & 1997 & 0.80 & 0.80 & 0.00 & -0.80 & -0.80 & 0.00 \\
\hline GTM & 1998 & 0.80 & 0.80 & 0.00 & -0.80 & -0.80 & 0.00 \\
\hline GTM & 1999 & 0.80 & 0.80 & 0.00 & -0.80 & -0.80 & 0.00 \\
\hline GTM & 2000 & 2.60 & 1.10 & 1.50 & -1.30 & -0.80 & -0.50 \\
\hline GTM & 2002 & 2.00 & 1.00 & 1.00 & -0.10 & 0.00 & -0.10 \\
\hline GTM & 2012 & 0.40 & 0.00 & 0.40 & 0.00 & 0.00 & 0.00 \\
\hline GTM & 2013 & 1.00 & 1.00 & 0.00 & 0.00 & 0.00 & 0.00 \\
\hline JAM & 1992 & 2.10 & 2.10 & 0.00 & 0.00 & 0.00 & 0.00 \\
\hline JAM & 1999 & 2.20 & 2.00 & 0.20 & -1.50 & -2.00 & 0.50 \\
\hline JAM & 2000 & 1.80 & 0.00 & 1.80 & 0.00 & 0.00 & 0.00 \\
\hline JAM & 2003 & 1.50 & 1.50 & 0.00 & 1.50 & 0.00 & 1.50 \\
\hline JAM & 2004 & 0.50 & 0.50 & 0.00 & 0.50 & 0.00 & 0.50 \\
\hline JAM & 2012 & 0.80 & 0.80 & 0.00 & 0.00 & 0.00 & 0.00 \\
\hline
\end{tabular}

Continued on next page 
Table B.1 - continued from previous page

\begin{tabular}{|c|c|c|c|c|c|c|c|}
\hline \multirow[b]{2}{*}{ Country } & \multirow[b]{2}{*}{ Year } & \multicolumn{3}{|c|}{ Announcement } & \multicolumn{3}{|c|}{ Credibility } \\
\hline & & Total & Tax & Spend & Total & Tax & Spend \\
\hline JAM & 2013 & 2.60 & 2.00 & 0.60 & 0.00 & 0.00 & 0.00 \\
\hline JAM & 2014 & 0.60 & 0.40 & 0.20 & 0.00 & 0.00 & 0.00 \\
\hline MEX & 1989 & 0.90 & 0.90 & 0.00 & 0.00 & 0.00 & 0.00 \\
\hline MEX & 2010 & 1.00 & 1.00 & 0.00 & -0.40 & -0.40 & 0.00 \\
\hline MEX & 2014 & 0.60 & 0.60 & 0.00 & 0.00 & 0.00 & 0.00 \\
\hline PRY & 1989 & 2.60 & 2.00 & 0.60 & 0.00 & 0.00 & 0.00 \\
\hline PRY & 2001 & 2.70 & 0.50 & 2.20 & -0.90 & 0.00 & -0.90 \\
\hline PRY & 2003 & 1.25 & 1.25 & 0.00 & 0.00 & 0.00 & 0.00 \\
\hline PRY & 2004 & 3.40 & 3.20 & 0.20 & -2.60 & -2.40 & -0.20 \\
\hline PRY & 2005 & -0.60 & -0.60 & 0.00 & 0.00 & 0.00 & 0.00 \\
\hline PRY & 2006 & -0.70 & -0.70 & 0.00 & 0.00 & 0.00 & 0.00 \\
\hline PRY & 2014 & 0.24 & 0.24 & 0.00 & 0.00 & 0.00 & 0.00 \\
\hline PRY & 2016 & 0.80 & 0.00 & 0.80 & 0.00 & 0.00 & 0.00 \\
\hline PER & 1992 & 1.00 & 1.00 & 0.00 & 0.00 & 0.00 & 0.00 \\
\hline PER & 1993 & 1.60 & 1.60 & 0.00 & -1.60 & -1.60 & 0.00 \\
\hline PER & 2002 & 0.16 & 0.16 & 0.00 & 0.04 & 0.04 & 0.00 \\
\hline PER & 2003 & 0.64 & 0.64 & 0.00 & 0.16 & 0.16 & 0.00 \\
\hline PER & 2011 & -0.39 & -0.39 & 0.00 & 0.00 & 0.00 & 0.00 \\
\hline PER & 2012 & 0.38 & 0.38 & 0.00 & 0.00 & 0.00 & 0.00 \\
\hline URY & 1990 & 1.70 & 1.70 & 0.00 & 0.00 & 0.00 & 0.00 \\
\hline URY & 1995 & 1.91 & 0.75 & 1.16 & -0.26 & 0.00 & -0.26 \\
\hline URY & 1996 & 0.25 & 0.25 & 0.09 & 0.00 & 0.00 & -0.09 \\
\hline URY & 2000 & 0.80 & 0.00 & 0.80 & 0.00 & 0.00 & 0.00 \\
\hline URY & 2002 & 2.77 & 1.58 & 1.20 & 0.50 & 0.00 & 0.50 \\
\hline URY & 2003 & 1.63 & 1.42 & 0.20 & 0.00 & 0.00 & 0.00 \\
\hline URY & 2004 & -0.43 & -0.43 & 0.00 & -0.07 & -0.07 & 0.00 \\
\hline URY & 2005 & -0.77 & -0.77 & 0.00 & -0.13 & -0.13 & 0.00 \\
\hline URY & 2015 & 0.60 & 0.00 & 0.60 & 0.00 & 0.00 & 0.00 \\
\hline
\end{tabular}

Elaborated by the author from David and Leigh (2018). For Colombia (1993 and 1996), Costa Rica (1993) and Dominican Republic (1995), the original documents could not be consulted. Therefore, a missing value has been assigned when the information was missing. 